\title{
CAPITELES HISPÁNICOS ALTOMEDIEVALES. LAS CONTRADICCIONES DE LA CULTURA MOZÁRABE Y EL NÚCLEO BIZANTINO DEL NOROESTE
}

\author{
POR \\ ENRIQUE DOMÍNGUEZ PERELA \\ Universidad Complutense de Madrid. Facultad de Bellas Artes
}

\begin{abstract}
RESUMEN
El estudio tiene por objeto el fenómeno cultural encerrado en las llamadas «Iglesias mozárabes». La conclusión del análisis correspondiente es que en ellas conviven dos universos culturales distintos: uno, relacionado con un influjo bizantino directo, que es posible situar en el siglo VI; y otro de manifiesto sentido rural, que corresponde a la cultura astur-leonesa. Asimismo se propone una revisión radical del concepto de «mozarabismo arquitectónico», que aquí se sustancia, más que en el uso de ciertos elementos formales, en un criterio «funcionalista» homólogo al de las primeras fases de la mezquita mayor de Córdoba, que se manifestaría en la reutilización sistemática de restos arquitectónicos y estructurales de épocas anteriores.
\end{abstract}

\section{SUMMARY}

The aim of this study is the cultural feature enclosed in the «iglesias mozárabes». The analysis conclusion is that in these churchs coexist two different cultural worlds. The first, which is relationed with at direct byzantine influence situate in the VI century. The other, with obvious rural sense belongs to «asturleonesa» culture. At the same time is propose a radical review about mozarabic architecture, which is based more than in the use of several formal elements, on a functional criterion homologous to the first phases of the great mosque of Cordoba which is shown in the systematic use of architectonic and structural rests of previous ages. 


\section{EL PROBLEMA DE LA CULTURA MATERIAL «MOZÁRABE»}

El más importante conjunto de capiteles de raigambre cultural bizantina aparecido en España ha llegado a nuestros días en los alrededores de la «frontera» occidental de la antigua diócesis de Astorga, definiendo un área que va desde las proximidades de León hasta los límites de la actual Cantabria. La mayoría han aparecido asociados a las llamadas «iglesias mozárabes" ', para las que, según las hipótesis tradicionales ${ }^{2}$, habrían sido realizadas. Sin embargo, desde mi punto de vista esa atribución debería ser revisada para subsanar las graves contradicciones que implica, desde los puntos de vista histórico, «artístico» y arqueológico 3 .

Como es sabido, el término «mozárabe», en un sentido similar al que hoy utilizamos, se consagró a finales del siglo pasado — concretamente a partir de 1897—, cuando se comenzó a publicar la obra de Simonet (Historia de los mozárabes en España), y quedó abierto el camino para localizar los restos materiales que correspondieran al hecho cultural enfatizado por dicho erudito; en ella y con independencia de toda matización etimológica, se entendía por «mozárabe" lo mismo que recogían los testimonios literarios posteriores a la toma de Toledo: cristiano que vive bajo el control institucional islámico (Simonet, 1983, t. I, p. VIII). Como es notorio, la empresa sería culminada por Gómez Moreno veinte años después, cuando tras un trabajo meticuloso, fue capaz de estructurar los objetos materiales que parecían corresponder a los datos de Simonet. Sin embargo, con la sistematización de Gómez Moreno, surgió la primera contradicción: la mayoría de las «iglesias mozárabes» conocidas (con la excepción de Melque y ¿Bobastro?) habían aparecido en zonas no sujetas al control institucional andalusí; es decir, la mayoría de las «iglesias mozárabes» no podían ser consideradas como tales en sentido estricto. Así pues, Gómez Moreno tuvo necesidad de matizar el término «mozárabe» en un sentido que parecía «natural»: el arte «mozárabe» no sólo sería aquel realizado por cristianos bajo control institucional islámico, sino también cualquier otro que respondiera al transfondo cultural latente bajo el fenómeno mozárabe. Surgía así la idea que aún permanece vigente y que, de hecho, se concretaba en aplicar el término «mozárabe» a los objetos materiales que manifestaran una fuerte dependencia respecto de la cultura hispanoislámica ${ }^{4}$, que en los casos más paradigmáticos, se sustanciaba documentalmente en la existencia de comunida-

' A mi juicio, el «problema mozárabe» y, en general, el problema de la cultura material de la Alta Edad Media española, tiene múltiples vertientes que he tratado de afrontar en artículos anteriores (especialmente en Domínguez Perela, 1984, 1987 y 1991) y que no reiteraré aquí más que en las cuestiones sustanciales.

${ }^{2}$ Gómez Moreno, 1919; las hipótesis de Gómez Moreno siguen siendo defendidas por S. Noack (ver Noack, 1991).

${ }^{3}$ El problema «mozárabe» tiene tantas vertientes que su análisis detallado requeriría una extensión incompatible con el carácter de este artículo. Para ver un «apunte sobre las cuestiones metodológicas y los modelos epistemológicos que han rodeado el conocimiento del «arte mozárabe», véase mi artículo publicado en el número anterior de esta misma revista, del que éste es, en cierto modo, continuación. Sobre lo allí formulado y a la vista de los reparos que se han puesto a mis planteamientos, de acuerdo con Dennet, tan sólo me resta recalcar que, por lo visto, las interferencias de ciertos sistemas de creencias (y los sistemas motivacionales subyacentes en ellos) parecen mantener una sólida barrera que dificulta considerablemente la comprensión de las cualidades más obvias de las culturas altomedievales hispanas.

${ }^{4}$ A mi juicio, esa ampliación del término, que hoy parece lógica, en aquella época encerraba varias 
des de «monjes» mozárabes (en sentido estricto) emigradas a territorios bajo control administrativo cristiano 5 .

Seguramente por las ambigüedades que, desde la perspectiva formalista, suponía un «estilo» tan peculiar y en paralelo a la crisis del concepto de «reconquista», Camón propuso el ajuste terminológico que implica el cambio de la denominación «arte mozárabe» por la de «arte de repoblación», que acaso pareciera más adecuado a la materialidad de los datos. Este cambio, que no resolvía las contradicciones subyacentes al fenómeno mozárabe tal y como había sido sistematizado, tuvo la virtud de imponer una revisión que condujo a replanteamientos como los de I. Bango en los que, sobre todo, comenzaban a cobrar vigor algunas de las cualidades que arropaban a los restos materiales adjudicados al siglo $X^{6}$. Más tarde, aparecerían las precisiones de J. Vallvé a propósito de Bobastro y, sobre todo, la tesis de L. Caballero que, al documentar la existencia de Melque en época preislámica, otorgaba una relevancia nueva a las reutilizaciones impuestas por la recuperación del culto cristiano. En cualquier caso y dejando para otros los matices terminológicos institucionales, ¿qué se podría esperar de la cultura «mozárabe», tal y como la dejó formulada Gómez Moreno? ¿En qué modo se debería concretar la cultura material de las comunidades mozárabes? Conociendo los altibajos de las relaciones entre cristianos y musulmanes durante los siglos IX y x y sin necesidad de emitir ningún juicio de valor, de algo podemos estar completamente seguros: los mozárabes - forzosamente- tenían que estar inte-

implicaciones de enorme trascendencia metodológica. La primera y la que ahora nos interesa, que de ese modo se creaba la categoría «arte mozárabe» con unas cualidades que desbordaban el concepto de "estilo artístico", puesto que con ello se otorgaba preeminencia a los atributos culturales sobre los institucionales. Así pues, en un contexto metodológico centrado en cuestiones formales e institucionales, el «estilo mozárabe», como también sucedió con el «estilo mudéjar», quedaba sustanciado a partir de una situación de relación cultural y no desde unas cualidades formales concretas y específicas.

s Es posible que al lector le sorprendan algunas de las afirmaciones e, incluso, algunas de las matizaciones realizadas hasta aquí. En relación a ello, debo hacer notar que durante el siglo $x$ —s decir, durante los años en los que se realiza lo más significativo del fenómeno mozárabe-, la situación administrativa de la península Ibérica sufre múltiples modificaciones que no se compaginan bien con lo que implica la vulgarización de los términos «reconquista» o «repoblación». De hecho, a lo largo del siglo x la independencia política y administrativa de los «reinos» cristianos del norte es cosa muy relativa. Por otra parte, también es conveniente resaltar que con el «arte mozárabe», como luego con el «arte mudéjar»-de circunstancias comparables- nos hallamos ante fenómenos de amalgama cultural difíciles de conciliar con toda visión histórica (metodología) fundada en una compartimentación sincrónica o diacrónica. En los ciclos mozárabe y mudéjar nos enfrentamos a fenómenos que resultan de la interrelación de dos complejos culturales en permanente evolución, que, en su contacto, precipitan resultados materiales híbridos, imposibles de comprender marginando cualquiera de los factores que los sustancian y, en especial, aquellos que responden a la realimentación que existen entre los sistemas generadores.

6 Como casi siempre ocurre, los planteamientos de Camón tenían mucho más trasfondo del que parece a primera vista; porque también con el «arte de repoblación» nos hallamos ante un «estilo de amalgama» definido en claves culturales, que ahora, con la denominación elegida y al margen de los problemas encerrados en el término «repoblación», son mucho más sensibles. De hecho, desde mi punto de vista y con las matizaciones que señalaré más adelante, esa denominación encajaría bien con lo que manifiestan los restos conocidos, con sólo matizar dicho término en claves institucionales; es decir, arte (cultura material) de la fase de «repoblación» institucional que llevó a cabo la monarquía asturleonesa (con independencia de que esa «repoblación» fuera tal a todos los efectos o un simple hecho administrativo, por el que los territorios pasaban a ser controlados por instituciones cristianas. 
grados en el sistema cultural andalusí, participando de unos usos y unas costumbres que, con la natural excepción de las circunstancias religiosas, serían sensiblemente comunes. Y naturalmente, entre esos usos y costumbres habría que situar los rasgos de cultura material; unos rasgos que, como en todos los sistemas culturales, siempre están condicionados y, en ocasiones, determinados, por las interrelaciones a que esa cultura material debe subordinarse. Así, por ejemplo, para la realización de cualquier tipo de escultura - ya sea un modesto relieve ornamental, ya un busto-, el artífice «hispano» del siglo $\mathrm{x}$ deberá someterse a los medios y las posibilidades del sistema cultural. De manera que un artífice o un grupo poco numeroso de artífices sólo podrá hacer uso de las canteras que estén en explotación y de las herramientas que les proporcionen los herreros; del mismo modo, sólo podrán emplear los «conocimientos generales» del entorno... En síntesis reiterativa, el «arte mozárabe» (la cultura material mozárabe) debería caracterizarse por ser, ante todo, un reflejo de la cultura material andalusí (inmediatamente anterior).

Y en términos formales, esa caracterización se ha pretendido sustanciar en el arco de herradura y en una concepción arquitectónica cualificada por la fragmentación espacial 7 ; cualidades que, unidas a la recuperación de algunas tradiciones de época visigoda y a un bizantinismo que se manifestaría, sobre todo, en los elementos ornamentales y, en especial, en los capiteles, conformarían lo más sustancial del paradigma «arte mozárabe».

En relación a ello, hay que exponer, en primer lugar, que los elementos formales sobre los que se hace gravitar el peso del influjo andalusí, no son rasgos culturales inequívocamente andalusíes, sino preislámicos, que fueron desarrollados en época visigoda ${ }^{\star}$ y luego en $\mathrm{Al}$-Andalus entre los siglos VIII y $\mathrm{x}$. De manera que, en principio, la existencia de arcos de herradura y de organizaciones arquitectónicas fragmentarias" en las iglesias «mozárabes» podrían ser explicadas al margen del influjo andalusí, en un marco probabilístico que incluye los flujos asturianos y que debería tener en cuenta la más que posible recuperación de los rasgos culturales preislámicos en un nuevo marco cronológico general.

¿Y el bizantinismo de los capiteles? ¿Cuál podría ser el origen de un influjo bizantino tan acusado como el que reflejan los capiteles «mozárabes»? Si hubiera sido posible llevar la cronología de estas iglesias hasta la segunda mitad del siglo $\mathrm{x}$ o al siglo XI, habría bastado con remitirse a la cultura andalusí " 1 o al reflujo de las Cruzadas... Sin embargo, a partir de las

${ }^{7}$ A pesar de lo mucho que se ha escrito en sentido contrario, resulta difícil encontrar en las iglesias mozárabes otros rasgos arquitectónicos supuestamente invariantes. En unos casos se emplean sillares bien labrados; en otros, mampuestos. Unas veces se utilizan sistemas completamente abovedados; otras, combinaciones de bóvedas y estructuras de madera. Algunas iglesias se aproximan a la planta basilical; otras, tienden a la organización centralizada; etc.

* Tampoco están exentos de «problemas» los restos materiales de época visigoda, en permanente revisión, que en un futuro no muy lejano, acaso impongan un replanteamiento radical, incluso de los fenómenos «formales» antes mencionados. Sin ir más lejos, los capiteles tradicionalmente considerados «visigodos», en mi opinión, y en términos generales, corresponden a fases cronológicas diversas, con frecuencia, anteriores a los siglos VI y VII.

9 El resto de los elementos arquitectónicos de las «iglesias mozárabes» presentan una dispersión que resulta contradictoria con la homogeneidad de los elementos ornamentales (los capiteles).

${ }^{10}$ El bizantinismo en las culturas hispanas del siglo $\mathrm{x}$ está documentado mediante documentos escritos en la época de al-Hakam, cuando se realizaron los mosaicos de la mezquita mayor de Córdoba y, de modo mucho más difuso, en los restos materiales de la época de Abd al-Rahmnan III, concretamente, en relación a las 
fuentes documentales, que obligan a retrasar la hipotética realización de los capiteles hasta principios del siglo $\mathrm{X}$, resulta que los influjos bizantinos aparecerían antes en tierras de León que en Córdoba. Y frente a los posibles antecedentes asturianos, resultaría algo aún más sorprendente: los elementos bizantinos de los edificios ramirenses resultan ser más degradados que los que aparecen en los edificios leoneses del siglo X. Dicho de otro modo: desde las hipótesis tradicionales, resultaría obligado admitir la existencia de un influjo bizantino directo (es decir, sin mediación de la cultura hispanoislámica o de la asturiana) que acaso pudiera ser justificada sabiendo que las relaciones entre Córdoba y Oriente están bien documentadas durante todo el siglo $X^{11}$. No obstante, esos supuestos contactos carecen de cualquier otro tipo de respaldo documental y, como veremos enseguida, chocan frontalmente con lo que reflejan los restos que deberían ser fruto de ellos y, aún, con los testimonios proporcionados por las fuentes literarias.

Por todo ello, se impone un replanteamiento del paradigma «arte mozárabe», desde las cualidades que, a priori y en términos culturales, es posible atribuir a unas comunidades originarias de Córdoba y asentadas en tierras leonesas, desde, al menos, el siglo IX y, con toda seguridad, mucho antes de la expansión edilicia del califato. Replanteamiento que, en primer lugar y por las razones ya expuestas, debería pasar por to que sabemos del foco cultural emisor. Si las comunidades mozárabes eran subsidiarias de la sociedad andalusí, es lógico suponer que en el aspecto arquitectónico esas comunidades se deberían manifestar solidarias con la concepción que, hasta entonces, habían manifestado los dignatarios cordobeses en ese sentido. Y da la ca-

obras realizadas en los salones del aparato de al-Zahra. Dentro de la cultura andalusí, el resto de los objetos en los que se han querido ver influjos bizantinos imponen no pocas dudas. En primer lugar, porque, a mi juicio, no están claras las atribuciones cronológicas de los restos islámicos anteriores al siglo x (véase Domínguez Perela, 1991) y en segundo lugar porque el bizantinismo de los restos anteriores a la época de al-Hakam también podrían explicarse advirtiendo que en $\mathrm{Al}$-Andalus existió un proceso cultural endógeno relativamente paralelo al que protagonizaron las áreas de gran influjo bizantino entre los siglos IV y x. En relación a ello, los influjos orientales de las iglesias mozárabes podrían obedecer a dos líneas de transmisión: la impuesta por un comercio de lujo canalizado por el norte o a través de Abd al-Rahman III en al-Zahra, es decir, a partir de los años centrales del siglo $\mathrm{x}$, de manera que nos veríamos obligados a adelantar la cronología de todas las «iglesias mozárabes» hasta la segunda mitad del siglo x. En el supuesto de que el influjo bizantino fuera fruto de una relación establecida al margen de al-Andalus, el hecho de que los restos «mozárabes» sean "más bizantinos» que los asturianos impondría que esa relación fuera directa, es decir, que hubieran existido contactos entre los monjes mozárabes y Bizancio (artífices o comerciantes) en un momento en que, al margen de un forzado «accidentalismo histórico», ni siquiera es posible pensar en esa posibilidad. En cualquier caso, la simple comparación de los influjos «bizantinos» que aparecen en las iglesias leonesas con los que se aprecian en Al-Andalus a partir de la época de Abd al-Rahman III, arroja unas diferencias de rango tales que resulta muy problemático conciliarlas con las cualidades culturales de ambas sociedades (fuertemente ruralizadas, en el caso asturleonés, y muy dependiente de modelos y sistemas de trabajo tardohelenistas, en el caso andalusí).

11 A modo de ejemplo, sabemos que en época de Abd al-Rahman III, Rabí (o Recemundo), obispo de Elvira participó en varias embajadas que, al menos en un caso, tuvieron como finalidad expresa la obtención de elementos ornamentales para los palacios de al-Zahra. Desde los datos que conocemos, cabría la posibilidad de que gracias a contactos de ese tipo, se establecieran relaciones entre las comunidades mozárabes y los cristianos de Oriente (bizantinos), que podrían haber dado fundamento histórico al influjo mencionado. Pero, con los datos históricos que conocemos, admitir esa posibilidad con anterioridad al año 936 (comienzo de las obras de al-Zahra) y, aún luego, resulta, cuando menos, muy forzado. 
sualidad que hasta mediados del siglo $\mathrm{x}$, la arquitectura hispanoislámica que conocemos se distingue por un detalle de excepcional importancia, al que creo se ha prestado poca atención: el rasgo de "utilitarismo" que presupone el uso de material de acarreo ${ }^{12}$. Un material que permitía construir con rapidez y, al tiempo, aseguraba un nexo de unión con las tradiciones locales de los que tan necesitados estaban quienes, al fin y al cabo, fueron contemplados como extranjeros.

Puestas así las cosas, desde el sentido semántico que reconocemos al término «mozárabe» y suponiendo que hacia el siglo IX, serían relativamente abundantes las edificaciones abandonadas al norte de Toledo ${ }^{13}$, las reutilizaciones asociadas al ciclo mozárabe dejarían de ser un rasgo circunstancial para convertirse en una cualidad sustancial, en el rasgo caracterizador de la cultura material mozárabe. Y desde ese previsible rasgo, el componente bizantino de las iglesias mozárabes cobra un sentido nuevo.

\section{LOS CAPITELES}

\section{A) Bamba}

En el lugar que se ha identificado con Gérticos apareció uno de los dos capiteles (VBA01, figura 1) más antiguos de la serie «mozárabe» ${ }^{14}$. Subsiste convertido en pila de agua bendita en la proximidad de impostas de pilastras ${ }^{15}$ perfectamente integrables en la serie que nos ocupa.

El capitel, de mármol y 40 centímetros de altura, es una derivación bizantina del corintio asiático y argumento contundente acerca de la existencia de un foco cultural bizantino en esta zona, porque, tal y como señaló Schlunk (1945, Relaciones, p. 193 y nota 2), «La confrontación con capiteles bizantinos de la segunda mitad del siglo v, por ejemplo R. Kautzsch, número 164 (de Constantinopla) no ofrece lugar a dudas: se trata de una pieza genuinamente bizantina, importada a España, o lo que es menos probable, trabajada en España por maestros griegos». Es prácticamente idéntico a uno de la llamada «basílica C», de Estambul (Firetli, 1974, pp. 168-169) 16; a otro de Cairuán (Harrazi, 1982, n. 343, ver figura 3) ${ }^{17}$ que se distingue por presentar distinta distribución de la corona

12 Como es natural, no quiero decir que no se haya advertido esta circunstancia, sino que no se le ha otorgado la entidad que, a mi juicio tiene, por encima, incluso, de otros rasgos de la arquitectura hispánica. De hecho, en términos de «aportaciones», la utilización masiva de material de acarreo - y lo que ello presupone desde el punto de vista arquitectónico y cultural - resulta ser el rasgo cultural más relevante (caracterizador) de la cultura islámica (hispanoislámica) durante los siglos VIII y IX.

13 Unos elementos que, por su vinculación a emplazamientos sacralizados de antiguo, debían poseer un cierto valor simbólico y religioso, porque en ellos se conservarían reliquias.

${ }^{14} \mathrm{El}$ otro sería un fragmento de capitel conservado en Toledo que parece muy similar a éste. Bamba es heredad de Recesvinto y lugar donde murió en 672 y donde fue elegido Wamba sucesor. Ver Gómez Moreno, 1919, p. 193 y ss.; también, Gómez Moreno, 1919, pp. 161 y 200-201; Schlunck, 1945, p. 193, nota 2; Schlunk, 1947, p. 242; Gómez Moreno, 1951, p. 378; Fontaine, 1978, p. 204.

is En el interior de la iglesia de Bamba se conserva una imposta de concepción estructural similar a los capiteles de Escalada y Peñalba, de los que se distancia por un tratamiento técnico sensiblemente más torpe. Es probable que se trate de restos de una fase cultural local en trance de disolución y, por lo tanto, posterior a la de aquellos. Siglos VI-VII. Ver Fontaine, 1979, p. 209.

16 Firetli lo situaba en el siglo VII («.... posteriores al reinado de Theodosio II y deben datar del si- 
de hojas y por otros pequeños detalles; otro del Museo de Mesina, que Agnello atribuye al siglo VII ${ }^{1 \times}$ (Agnello 1966, n. ${ }^{\circ} 10$ ) también es muy similar ${ }^{19}$; otros dos de Rávena (Farioli, CSA Ravenna, n." 16, de la Iglesia de Santa María Mayor, y el n." 18, del Museo Nacional), ambos atribuidos al siglo VI, presentan un indudable parentesco con el de Bamba. Además de estos paralelos, hallamos piezas con acanto muy espinoso, sin caulículos, con volutas dobles y con florón, muy similares a los anteriores, en San Juan Bautista, de Jerusalén y, sobre todo, en el Egipto copto ${ }^{20}$.

A destacar que, frente a las modalidades más repetidas de las series que veremos más adelante, en éste no se ha empleado el trépano con valor plástico y que, por lo tanto, nos hallamos ante una concepción estética distinta de la que expresan las series de Escalada, Sahagún, Peñalba y áreas próximas. Otro tanto sucede con los brazos del ábaco, que aquí son curvilíneos, frente a lo más habitual en las iglesias mencionadas.

En definitiva, sin variar un ápice la apreciación de Schlunk, debemos situar este capitel de Bamba entre la segunda mitad del siglo $\mathrm{V}$ y los primeros años del VI, en el seno de un fenómeno de expansión cultural bizantino sin ninguna aportación local. Lo que supone el primer dato positivo extraído directamente de este tipo de piezas: el capitel de Bamba nos asegura la existencia de un influjo cultural bizantino directo a partir de un momento incierto situado en los alrededores del año $500^{21}$.

\section{B) San Cebrián de Mazote}

El segundo grupo de piezas aparece en San Cebrían de Mazote ${ }^{22}$. El primer análisis de interés al respecto obedece a la pluma de Gómez Moreno (1919, p. 175), que advirtió la existencia

glo VII»); no obstante, hay que tener en cuenta que su artículo está fechado en el año 1949. Firetli mismo, en el mencionado artículo habla de «un capitel idéntico ha sido encontrado en el Palacio de la Magnaura», que habría sido publicado por Mamboury, E. y Wiegand, Th.: Kaiserpaläste von Konstantinopel, Berlín, 1934, pl. CXVII, y que no he podido localizar.

17 Harrazi considera que el de Cairuán, prácticamente idéntico al de Bamba, fue tallado en Constantinopla. En todo caso, no parece que para esa época, se pueda hablar de un comercio de capiteles o de mármol muy activo. Para seguir el problema desde sus comienzos, ver Ward Perkins, 1980.

is A tenor de la ordenación cronológica que aparece en el artículo, dicha atribución pudiera ser una errata.

${ }^{19}$ Este del Museo de Mesina presenta en la zona bulbosa un motivo ornamental inciso que, como advierte Agnello, debe ser de época posterior. En todo caso, es una pieza de dimensiones prácticamente idénticas a las de Bamba que, además, marca un fenómeno comparable al del noroeste de la península Ibérica. También allí aparece una serie de piezas de manifiesto carácter bizantinizante pero de fuerte personalidad propia.

20 Ver Severin, 1981.

${ }^{21}$ El fragmento de Toledo permitiría creer que este primer influjo bizantino no se restringió al área leonesa. Sin embargo, su carácter insular, la existencia de restos de manifiesto influjo bizantino anteriores al siglo vı en el noroeste de la península Ibérica, y lo que veremos a continuación, permiten apuntar en dirección contraria, esto es, que el fragmento toledano fue transportado a Toledo, muy probablemente, desde la zona leonesa.

${ }^{22}$ La iglesia está documentada en el cartulario de San Martín de Castañeda, en el año 952, cuando se renueva una autorización dada, al parecer, en la época de Ordoño II, a propósito de los derechos de pesca en el lago de Sanabria (Fontaine, 1978, p. 199): «... los hermanos de Castiñeira, quienes habíamos vivido anteriormente en Mazote con nuestro abad Martín...». 
de series de adscripción cultural diversa, desde la época romana hasta la asturiana. Así pues, nos hallamos ante el primer dato explícito que contrasta de manera positiva la hipótesis mencionada: San Cebrían de Mazote refleja con claridad meridiana ese utilitarismo arquitectónico que podemos relacionar con la cultura andalusí. De todas las series allí documentadas, interesa destacar las siguientes:

b.1) Capiteles corintizantes. Grupo $\mathrm{CCCl}$. Serie definida por un conjunto de capiteles (figura 4) de manifiesta homogeneidad modular, que hoy aparecen adosados pero que fueron tallados por las cuatro caras, por lo tanto, para un lugar distinto al actual. Todos ellos tienen una altura próxima a los $32 \mathrm{~cm}$. y una anchura que oscila entre los 40 y los $42 \mathrm{~cm}$., lo que asegura de su común procedencia. Carecen de collarino. Constan de cesto de ocho hojas, más cuatro en los ángulos, volutas exteriores, que culminan en rollo helicoidal, y cálato con labio, que alberga un motivo vegetal con piña central, agrupación de cinco hojas con eje inciso y dobles espirales con diminuto tallo que llega al florón que, a veces, es un disco solar. El ábaco está perfectamente articulado con brazos curvos, al modo romano. Las hojas, muy simplificadas, conservan, no obstante, la idea del acanto; aunque no se empleen ojales, existen limbos plegados hacia el interior. Únicamente el tipo de talla, de escaso relieve, nos remite hacia usos posthelenistas. A juzgar por su fuerte dependencia de las variedades corintizantes y en concreto, con algunos prototipos romanos muy conocidos, nos hallamos ante capiteles que nos hacen pensar en la posible existencia de un foco de cultura tardorromana que acaso hubiera que relacionar con la expansión de las villas, probablemente hacia el siglo IV. No obstante, el indudable parentesco del tipo de talla de estos capiteles con algunas de las series de fuerte influjo bizantino, la constancia de que en estas últimas manifieste un fuerte rezago de cultura «helenista occidental» y el hecho de que existan fustes con el borde doblemente sogueado (ver pieza VMZ23), nos obliga a considerar también la posibilidad de que, en realidad, fueran realizados en un momento posterior, como aportación local al proceso constructivo de impronta bizantina. Así pues, deben clasificarse en la banda cronológica comprendida entre los siglos IV y VI, a la espera de nuevos datos que permitan mayor precisión.

b.2) Capiteles pseudocorintios de collarino «laureado». Grupo SCM1. Está compuesto por cuatro capiteles ${ }^{2.3}$ (figura 5) en aceptable estado de conservación, de relieve somero, que poseen collarino - en tres casos, laureado y en otro, anómalo-, abocelado en liso, cálato poco marcado, dos coronas de hojas repartidas entre el cesto y el cuerpo superior, volutas exteriores y ábaco de escasa articulación y con brazos rectos; carecen de caulículos y de volutas interiores; las exteriores, rematadas en espiral, arrancan de la hoja central del segundo nivel, según fórmula relativamente frecuente desde las modalidades teodosianas. El cálato es bulboso, como en los capiteles «de medallón». Tanto estructural como ornamentalmente es el grupo vinculado más directamente con las fórmulas usadas en Constantinopla (Kautzsch, 159, 162 y 163), como en el caso del capitel de Bamba, con paralelos entre los reutilizados de Cairuán (figura 6). Las hojas del cuerpo superior siguen modalidad muy frecuente en la talla bizantina de los siglos $\mathrm{V} y$ VII, mediante grandes foliolos biselados con ojales triangulares y alargados, sin que se marquen

${ }^{23}$ Lampérez, 1902; 1904; 1916; 1930, t. I, p. 235; Gómez Moreno, 1919, p. 172-185; Schlunk, 1945; Puig i Cadafalch, 1961, lám. XL; García Romo, 1973, p. 127, nota 2, fig. 33 y 34; Pita Andrade, 1975, p. 112-115; Fontaine, 1978, p. 181 y ss. 


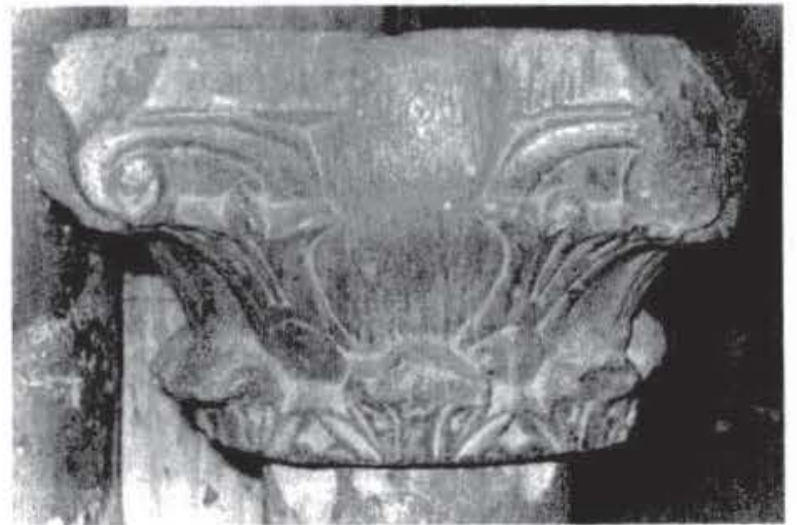

Figura 1. Capitel de Bambal.

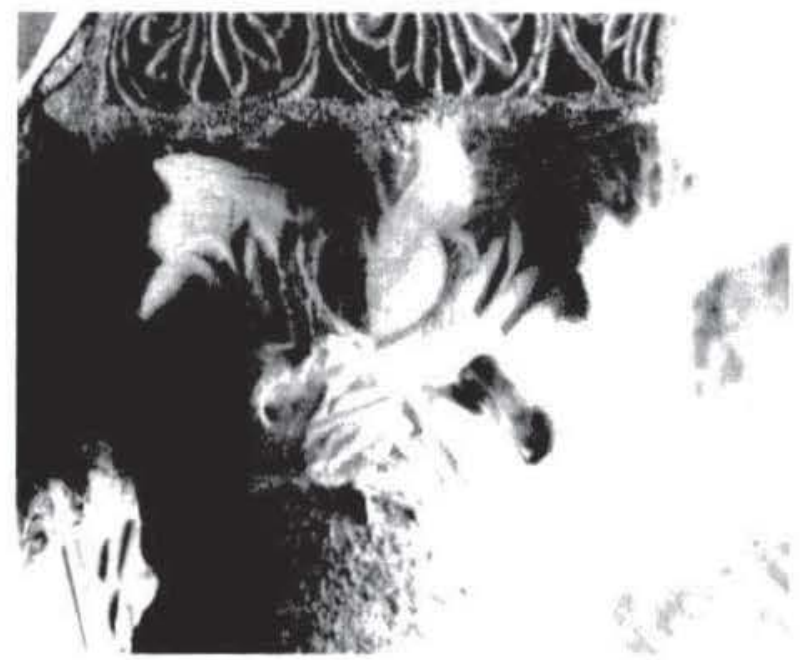

Figura 3.-Cairuán.

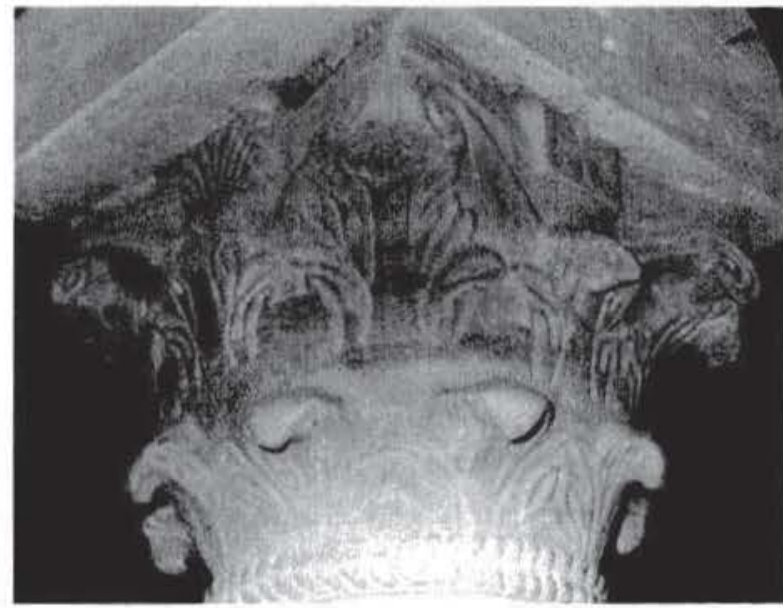

Figura 5. - San Cebrián de Mazote (VMZ04)

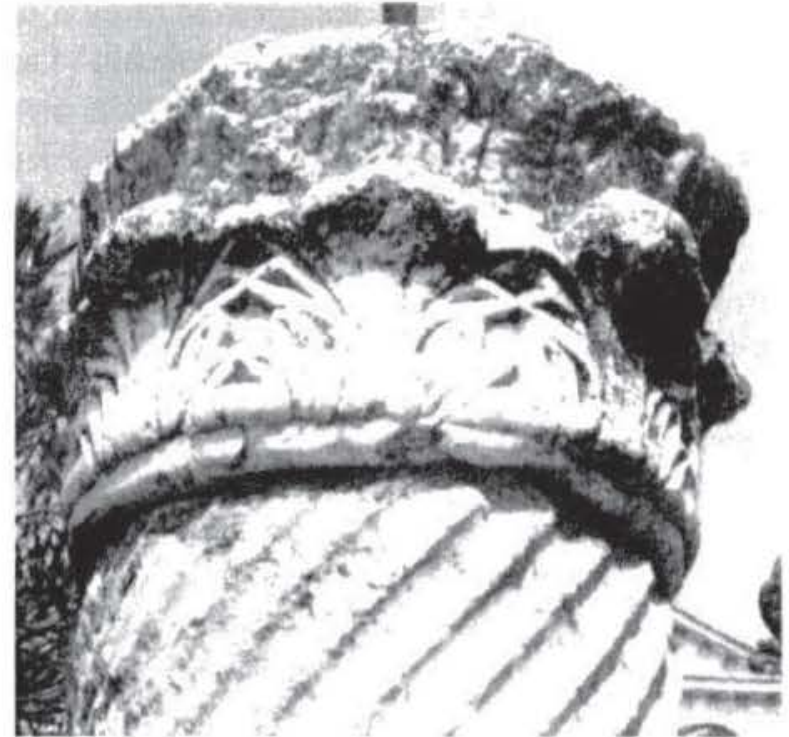

Figura 2.-TSEOI. Toledo. Cristo de la Vegia

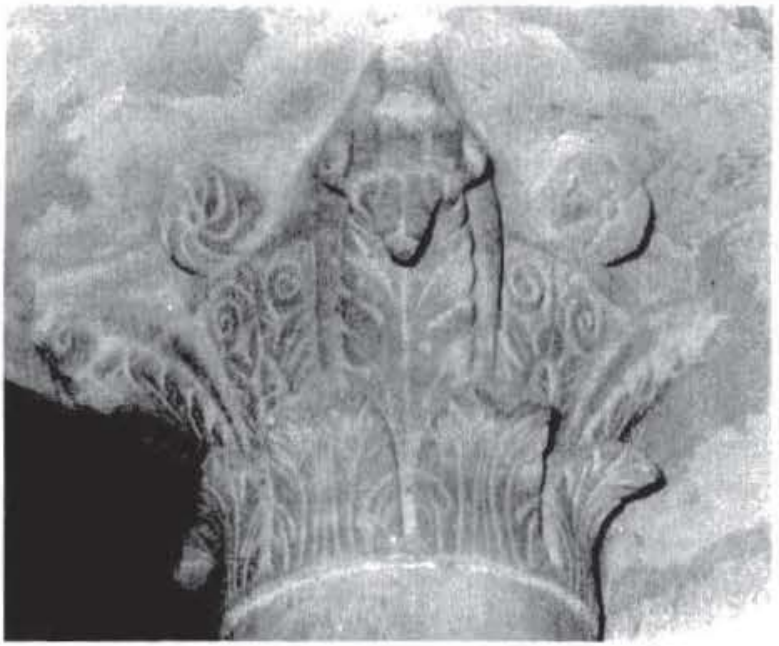

Figura 4.-San Cebrián de Mazote (V M/16)

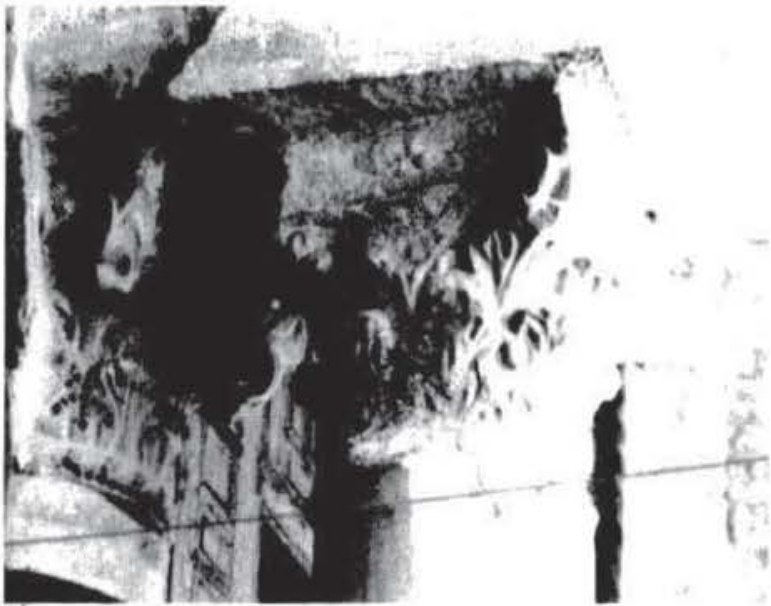

Figura 6.-Cairuán. 
trepanaciones, como las del capitel de Bamba; las del cesto contienen anillos muy redondeados - conseguidos mediante el uso del trépano-, que parecen rasgo local y que, con una interpretación u otra, veremos con cierta frecuencia en todo el conjunto de collarino laureado. Las cartelas integran brácteas, veneras y flores, también frecuentísimas en lo oriental de estos años, así como las letras que presenta uno de ellos. Sin duda lo más interesante de la serie está en la convivencia de fórmulas bizantinas en sentido estricto - las hojas del cuerpo superior-al lado de otras - las hojas del cuerpo inferior y, tal vez, el carácter dibujístico de las volutas exterioresde sentido más original — si se quiere, local- que caracterizan al grupo y pone en conexión - dentro de una secuencia cronológica relativamente breve-, a las piezas más tempranas —el capitel de Bamba - con las que marcan el paso siguiente: los capiteles de Sahagún y los de Escalada, en los que se opta por acentuar los rasgos creativos - locales-, dejando a un lado las fórmulas bizantinas ortodoxas ${ }^{24}$. Aunque no me fue posible medir las huellas de las cabezas de los trépanos, a juzgar por el tipo de talla, creo que las herramientas utilizadas no se diferencian mucho de las que se emplearon para tallar las series de Escalada: seguramente, el collarino sería realizado mediante trépanos de 2 ó 3 milímetros mientras que las anulaciones de las hojas se obtendría mediante trépanos cónicos de unos 5 ó 6 centímetros.

Uno de los rasgos más característicos de esta serie y de todos los capiteles del área leonesa lo hallamos en el collarino que, por la parte inferior, limita al cesto. Un collarino que, siguiendo a Gómez Moreno, podemos denominar «laureado» y que, con las mismas cualidades —en la misma situación - no he conseguido documentar en el ámbito bizantino en parte alguna, dentro del amplio contexto al que es posible atribuir todas estas piezas; circunstancia que, incluso, en el supuesto de que exista algún capitel similar en algún punto ignorado, nos asegura de su singularidad y rareza. En todo caso, con los datos que conocemos, es posible establecer dos hipótesis para acotar su procedencia: como elemento aislado, es decir, como collarino «doblemente sogueado» o como estilización de la laurea.

a) Collarino doblemente sogueado. El único «precedente» literal que he conseguido documentar en este sentido se halla en un capitel romano, del Museo Nacional (n. ${ }^{\circ}$ de Inv. 891) (figura 7), con aspecto de cesto, labrado en «mármol griego» y atribuido a los siglos II-III, que, según Grüneisen ${ }^{25}$, es documento fundamental para explicar la aparición de los capiteles cesto bi-

${ }^{24}$ Contemplando todos estos capiteles en conjunto, da la sensación de que nos hallamos ante unas series creadas por un «taller» - por un único «impulso cultural»_ que, partiendo de fórmulas estrictamente bizantinas, una vez arraigado en el noroeste español, acaba dando vía libre a la creatividad de los tallistas, pero sin que éstos lleguen a romper con los fundamentos de su origen, del mismo modo que sucede, por ejemplo, en Egipto en época Copta. Ver Severin, 1981, capiteles de las fig. 1 (Ahnas), 3 (Ashmunain) y 4 (Convento Rojo); los paralelismos entre esta serie de Mazote y ellos son muy claros, sobre todo, en la «manera» de interpretar el orden y en detalles como la vuelta de las hojas, el acanto afilado, el tipo de relieve, algo más carnoso en los egipcios. Sobre el origen de estas modalidades ornamentales, véanse, sobre las interpretaciones orientales — sirias - de las fórmulas romanas, en las que se fundará el desarrollo posterior: Krencker, y Zschietzschmomn, 1938, p. 233 y ss. (capiteles muy evolucionados del templo de Hermon); Brusin, 1934 (fig. 143, pieza tardía, «oriental», con hojas de punta, del siglo II; fig. 107, p. 181, capitel corintio del siglo I, muy evolucionado; pp. 97 y 98 , fig. 44, capitel con hojas de punta, siglo II). Y para el desarrollo de las fórmulas decorativas en los elementos arquitectónicos en general: Venditti, 1967 y Talbot Rice, 1935.

25 Museo Nazionale, Le sculture, 1,2, Roma, 1981, n. ${ }^{\circ} 19$, pp. 99-100. 
zantinos. En él se ha utilizado un doble sogueado exactamente igual a los que aparecen en los capiteles leoneses, pero en lugar de estar en la parte inferior del cesto, se encuentra a media altura, en el cuerpo inferior, para separar el diferente tratamiento superficial del cesto y, al parecer, para delimitar la parte inferior del «ábaco». Desde la idea que subyace en ese capitel, podríamos suponer que el doble soguedo de nuestros capiteles sería un motivo estrictamente ornamental de naturaleza semejante, empleado para acentuar la separación entre el fuste y el cesto del capitel ${ }^{26}$.

b) No obstante, también cabe la explicación que, implícitamente, se hallaba en la denominación utilizada por Gómez Moreno, de «collarino laureado». Y es que, en lo bizantino es muy frecuente el uso de este elemento, más o menos estilizado, para determinar compartimentaciones, como vemos en algunos capiteles de Santa Sofía (figura 8). Asimismo, son numerosos los capiteles «de zonas» ${ }^{27}$ que, como los de Rávena (figura 9), emplean el motivo de la láurea estilizada para ornar la parte inferior del cesto con carácter de collarino. El desarrollo de este tipo de fórmulas pudo desembocar en soluciones como las que presentan algunos capiteles de Rávena (figura 10, Rávena, Museo Nacional) ${ }^{28} \mathrm{o}$ los leoneses.

Sea como fuere, con mayor o menor esquematización ${ }^{29}$, este motivo se convierte en invariante y caracterizador de esta serie y en motivo utilizado con mucha frecuencia, como elemento «marco» para configurar áreas, en la decoración de época visigoda y en la asturiana, de donde, según las hipótesis tradicionales, habría sido tomando por los tallistas «mozárabes» (como es natural, desde mi punto de vista, habría que invertir el sentido del

${ }^{26}$ Pensabene, 1982, pieza n." 87, p. 64 y lám. 67, a propósito de un curioso capitel muy «degenerado», del siglo IV, habla de «espina pez" para referirse a un "collarino» comparable a los de las series leonesas, situado en zona de unión al fuste. Tal denominación sería de todo punto inapropiada en nuestro caso.

27 Sobre los capiteles de «dos zonas», en los que aparece este motivo de la láurea, ver, además de la bibliografía de carácter general: Firatli, 1974; Vergara, 1981, pp. 80-82, la pieza D-6, siglo V1, presenta bocel decorado con estrías dispuestas en «espinas de pez» — ¿en láurea estilizada? - (esta pieza atribuida por Wackernagel al siglo XI: Wackernagel, 1991, p. 60; no obstante, esta atribución ya había sido modificada por Colasanti, 1923, que la situó en el vi); las piezas C-6 y J-5, del siglo VI, también presentan collarino similar; otro tanto sucede con las D-6 y C-6, fechados en relación a los de San Clemente, de Roma, realizados con seguridad entre 514 y 524. Para estos últimos capiteles: Deichmann, 1965 y Kautzsch, 1936, p. 163 y ss. También CSA, Cividale del Friuli, 445, atribuido a la primera mitad del siglo VIII; Vergara, 1981, pp. 71-103; Raspi Sierra, 1972, p. 139, figs. 7 y 8 (en relación a estas piezas: Bertaux, 1904, I, pp. 75-76, supone que serían realizadas en el siglo Vı en el Proconneso para la explotación; también Fairoli, 1964, que realiza una tipología de los capiteles de «dos zonas». Fevrier, 1978, sobre el de Arles. El uso esporádico de collarinos de cordón también está documentado en el ámbito romano (Harrazi, 1982, n. ${ }^{15}$, p. 46) y, sobre todo, en Oriente, como de costumbre, en el seno de las corrientes bizantinas (Harrazi, 1982, n. ${ }^{\circ} 376$, p. 166, bizantino de collarino doblemente foliáceo; $n .^{\circ} 236$, del Museo de Cartago, siempre antes del año 600). Raspi Sierra, 1973, fig. 13, p. 214 y fig. 17, con sogueado tipo Escalada, también en el siglo vı. Para las zonas más orientales: Schlumberger, 1933, varios capiteles con sogueado de cordón, del templo de Soueida, láms. XXXIV-3, XXXV-1-2, XXXVI-1-2; Weigand, 1924, también recoge varios capiteles con sogueado de cordón.

28 Ver Farioli, 1969, n. 58.

${ }^{29}$ Casi de modo anecdótico podemos citar un capitel copto, aparecido en Faras, de estructura muy evolucionada, con trepanaciones sueltas, ábaco apenas articulado, que, a modo de "volutas vegetales», presenta largas hojas de foliación seriada, de aspecto similar a una láurea estilizada (estilizadísima), que Ryl-Preibisz clasifica entre finales del siglo V, principios del VI. 
flujo) ${ }^{30}$. Por lo que ahora interesa, con esta serie estamos absolutamente seguros de la existencia de unos rasgos culturales directamente vinculados con el capitel de Bamba que, por lo tanto, informan del desarrollo de lo que ello suponía pero, ahora, con aportaciones de carácter «local", que, en este caso, no parecen ser una aportación de los rasgos culturales autóctonos, sino desarrollo creativo del foco cultural emisor. Dicho en otros términos: estos capiteles de Mazote parecen ser obra de un «taller» de individuos formados en el seno de la cultura bizantina, que con cierta autonomía, optan por desarrollar fórmulas decorativas originales, de concepción muy próxima a la que aparece en el capitel de Bamba y de la que son claros continuadores.

b.3) Grupo SCM2 (pseudocorintios de collarino laureado). Existen dos capiteles de mayor alto que ancho (figura 11), en su carácter de testimonio cultural, perfectamente integrables entre los demás de collarino sogueado. Como sus compañeros, presentan dos coronas de hojas con series de foliolos relativamente alejados del acanto tradicional, pero muy próximos a las fórmulas orientales, de las que se distinguen por una cierta estilización —-sin llegar a la geometrización-; lo más destacable de estas formaciones de hojas es la inclusión de una, diminuta y curvada, que marca ojal circular, comparables a las que veíamos en las coronas inferiores de la serie anterior. Sobre las esquinas se han colocado "volutas» que no son sino un cordón desarrollado hasta adquirir forma espiral. El cálato está, como en la serie anterior, levemente insinuado, y el frente del ábaco presenta ornamentación de perlado. Las cartelas contienen palmetas. Lo más llamativo se encuentra en la manera de acodar la vuelta de las hojas angulares, que a algún autor le sugirieron formas animadas, y que no son sino columnillas lisas o torsionadas. También es interesante en esta serie el uso, en el cuerpo superior, entre las cartelas y la hoja axial de la segunda corona, de unas palmas aveneradas, semejantes a las de las cartelas del grupo anterior. Junto a ellas existen unos diminutos casquetes con discos de radios curvos, muy frecuentes en lo bizantino y en la ornamentación de época visigoda que, por supuesto, también podemos suponer de contenido simbólico. Como en la serie anterior, también se advierte el uso de trépanos de punta cónica de cualidades similares a lo que también señalábamos a propósito de aquella. El cálato ha perdido parte del carácter bulboso que antes indicábamos y el ábaco ofrece una articulación peculiar. Sus rasgos de reutilización son mucho más claros que en la serie anterior: no existe correspondencia entre la parte inferior del cesto y el fuste y el tamaño del dado superior tampoco guarda acuerdo con las dimensiones del ábaco ${ }^{31}$. Aunque sus rasgos estructurales y formales presentan una manifiesta evo-

30 También existen precedentes en el mundo hispanorromano, en un vaso de vidrio procedente de Termantia (Soria) con borde sogueado y doble sogueado y de un vaso de terra sigilata de Almendralejo compartimentado con espiguilla (Taracena, 1947, fig. 160, fig. 167), en confluencia formal con los motivos de espiguilla estilizada. Y, desde luego, acaso con una confluencia similar, también lo hallamos en los iconostasis de Santa Cristina de Lena (Schlunk, 1947, fig. 269); es motivo habitual en las culturas mediterráneas tardorromanas y, desde luego, en la época de gran influjo bizantino. A propósito de este motivo, ver también las piezas procedentes de la basílica de Breviglieri (Al-Khadra) (De Angelis D'Ossat y Farioli, 1975, cat. n. 1 a 9). También presenta una configuración formal muy similar a los collarinos de estos capiteles las láureas —en sentido estricto- de algunos relieves italianos altomedievales; ver, por ejemplo, Panazza, 1966, pieza n. ${ }^{\circ} 4$ (de Brescia).

${ }^{31}$ Más adelante, a propósito de Lebeña y Peñalba tendremos ocasión de ver cómo se concreta esta correspondencia. Aquí sorprende, sobre todo, la desproporción que existe entre el dado de arranque de los arcos - no parece que, en este caso, se pueda hablar de cimacio-y el ábaco. La "organicidad» estructural impondría en este caso un cimacio piramidal (o prismatoide) de base cuadrada. 


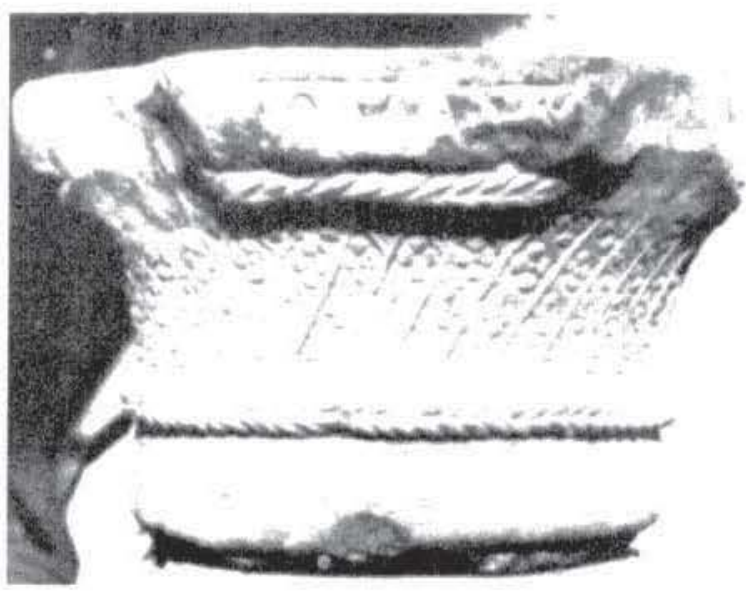

Figura 7.- Roma, Museo Nacional (n. inv. 891).

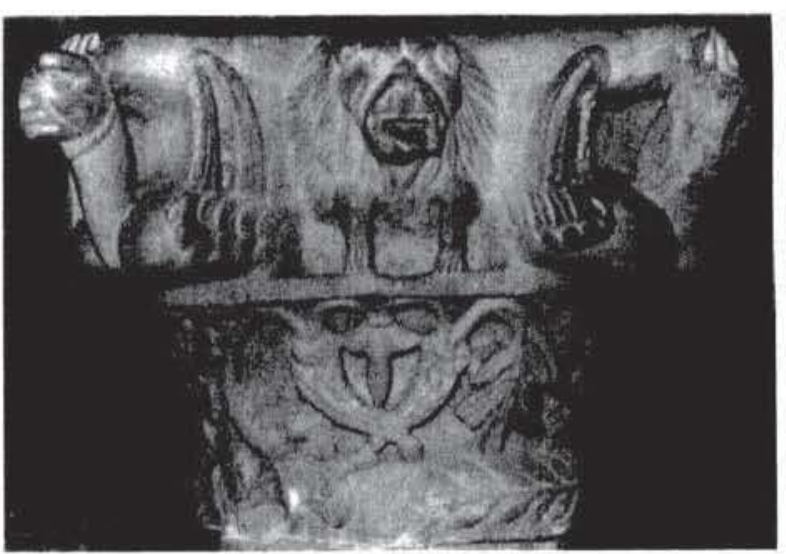

Figura 9.-Rávena, Museo Episcopal.

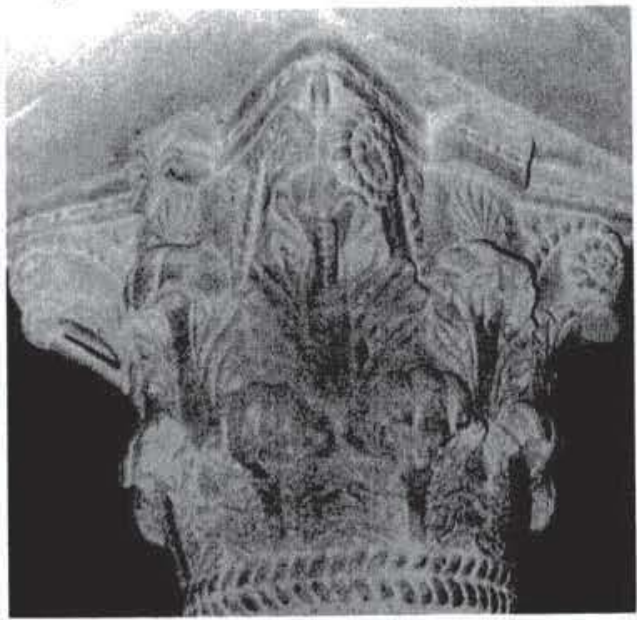

Figura 11.-San Cebrián de Mazote (MVZ24).

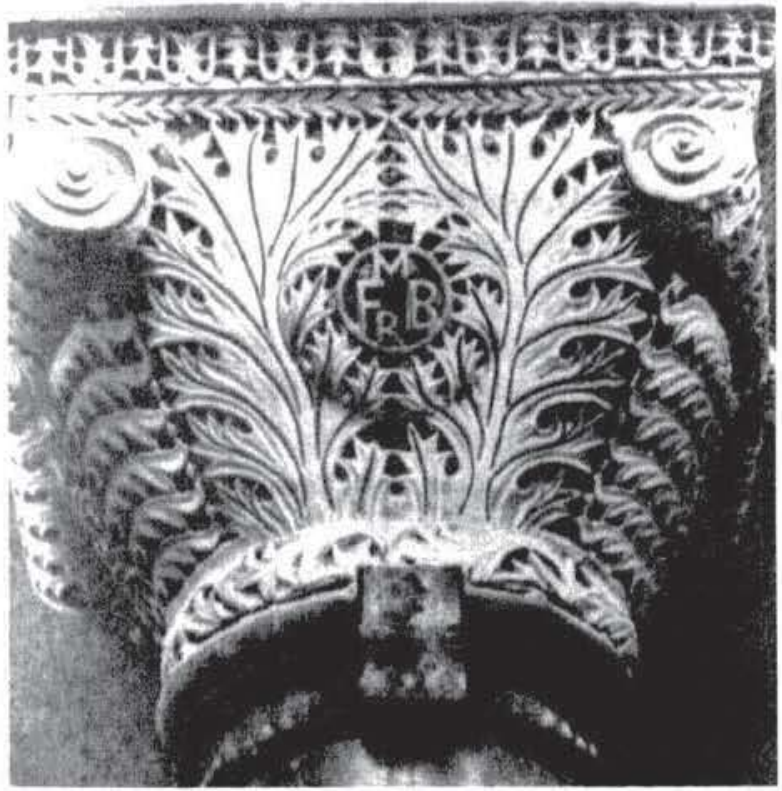

Figura $x$. - Santa Solía.

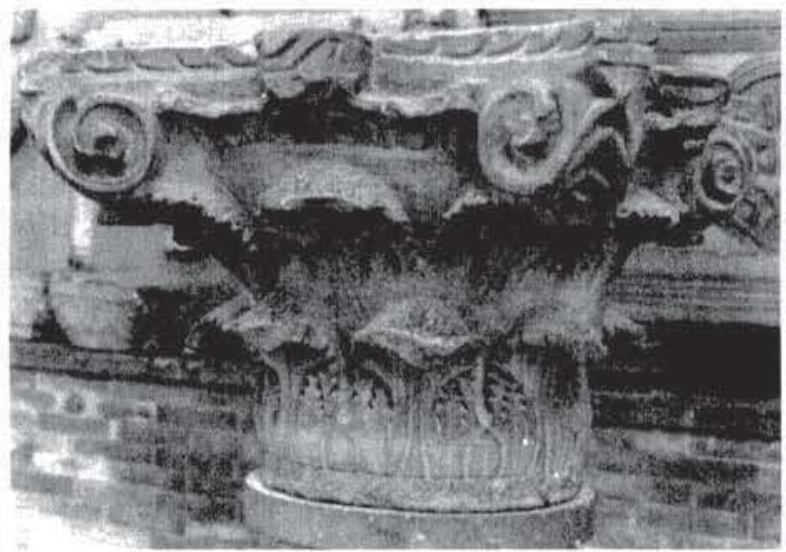

Figura 10.-Rivena. Museo Nacional.

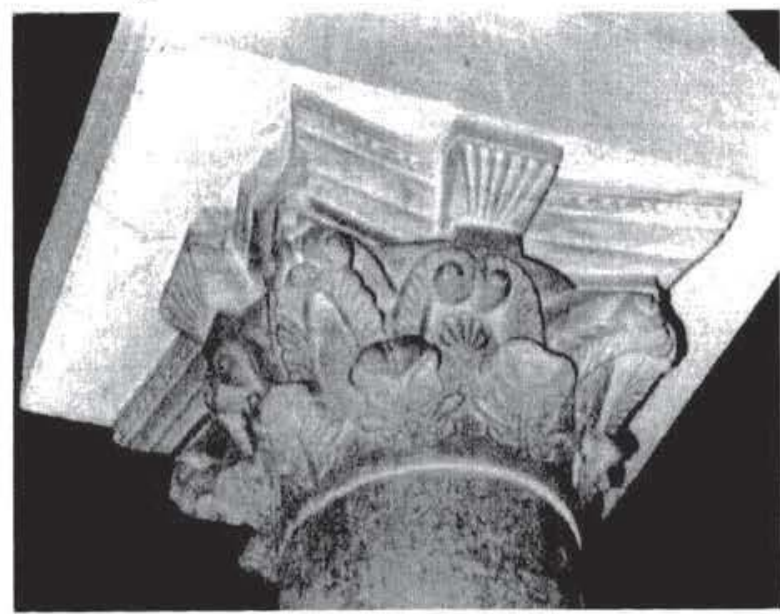

Figura 12.-San Cebrián de Mazote (MVZ03). 
lución - si se quiere, una cierta «barroquización»-, no parece probable que fueran realizadas mucho después que los anteriores. Sencillamente, nos hallamos ante capiteles que, por su vinculación a la serie SCMI e, indirectamente, al de Bamba, siguen señalando en la misma dirección cronológica y cultural, aunque por sus peculiaridades, acaso informen de una «mano» distinta de la que realizó los anteriores o, sencillamente, de otro gesto creativo...

b.4) Serie SCM4 (Pseudocorintios). Lo componen dos piezas más clásicas que las anteriores (figura 12), que descansan sobre dos fustes de concepción arquitectónica dispar, lo que de nuevo, nos permite plantear la segura reutilización de unos y otros. Sobre un collarino recompuesto, surgen ocho hojas con series de dos foliolos, uno grande y enhiesto y otro encurvado y pequeño, comparables a los que hemos visto en las series anteriores y a las que veremos en Escalada y Peñalba. Poseen dobles volutas, con cáliz adherido por la parte inferior y que culminan en hélices perfectamente marcadas, casi al modo "clásico». El conjunto axial está sustituido por una palmeta, en unas ocasiones y en otras, por un motivo vegetal de composición simétrica que también aparece en el hueco dejado por las volutas angulares de uno de los capiteles. El cálato está perfectamente marcado, al modo tradicional, y el ábaco es de brazos rectos con cartelas rectangulares lisas. La talla es también somera y con trepanaciones cónicas de valor plástico. Sobre ellos se conservan sendos cimacios ${ }^{32}$, de escaso espesor, moldurados y ornados con palmetas muy geometrizadas, contarios y sogueados, que muy probablemente fueron concebidos originariamente con estos capiteles, puesto que las dimensiones y la ornamentación de unos y otros concuerdan. En todo caso, este detalle informa de una concepción estética de cierta sofisticación, ajena a lo más habitual en el seno de las soluciones ornamentales bizantinas pero tampoco demasiado distante a ellas. Así, por ejemplo, sin guardar un paralelo literal, la configuración del cuerpo superior de estos capiteles y, en especial la forma de las volutas, marcando arista con el cálato, es muy similar a la que, para el mismo detaIle, hallamos en algunos capiteles de Cairuán (Harrazi, en especial, el n. ${ }^{\circ} 365$ ). Si se nos permite el símil, estos capiteles parecen ser el resultado de fundir lo que de «oriental», o «bizantino» hay en las series anteriores, con fórmulas directamente tomadas de la tradición helenista occidental - también sujeta, a su vez, al influjo oriental-y con aportaciones propias de fuerte componente helenístico. Es por tanto, la serie «más clásica» de todo el conjunto de Mazote y una de las que nos hacen dudar de si, en realidad, no estaremos ante capiteles realizados con anterioridad al siglo $\mathrm{V}$.

${ }^{32}$ Estos peculiares «cimacios» componen uno de los rasgos más sobresalientes de la ornamentación arquitectónica asociada al ciclo cultural que tratamos. Seguramente por sus anómalas proporciones han sido denominados «sobreábacos» y, realmente, no faltan razones para ello, toda vez que parecen ampliaciones del ábaco, muy adecuadas a la estructura lisa de esa parte en la mayoría de los capiteles leoneses. En todo caso, da la sensación de que esa original solución sólo fue ensayada en pocos casos, puesto que el resto de los capiteles que conocemos (Escalada, Peñalba y Sahagún) han aparecido asociados a cimacios estructuralmente más convencionales, con ornamentación muy esquematizada de perlados, que pudiera derivar de la molduración de los de Mazote. Sea como fuere, nos hallamos ante un rasgo cultural (otro más) que carece de precedentes hispanoislámicos y que, por su sentido orgánico y por su aparición en un contexto rural, nos hace pensar en soluciones creativas que sólo pueden tener sentido en el seno de una șociedad muy vinculada aún a las tradicionales helenistas. Entre lo que más se aproxima a estos elementos ver Duval N. y Lézine, A., 1959, p. 130. 


\section{C) San Miguel de Escalada}

También es muy curioso el problema de San Miguel de Escalada ${ }^{33}$, documentado gracias a una lápida perdida y conocida a través de Risco: «Este local, de antiguo dedicado en honor del arcángel Miguel y erigido en pequeño edificio, tras caer en ruinas, permaneció largo tiempo derrotado, hasta que el abad Alfonso, viniendo con sus compañeros de Córdoba su patria, levantó la arruinada casa en tiempo del poderoso y serenísimo príncipe Alfonso. Creciendo el número de monjes, erigióse de nuevo este hermoso templo con admirable obra, ampliado por todas las partes desde sus cimientos. Fueron concluidas estas obras en doce meses, no por imposición autoritaria ni oprimiendo al pueblo, sino por la vigilancia insistente del abad Alfonso y de los frades, cuando ya empuñaba el cetro del reino García con la reina Mumadona, en la era 951, y fue consagrado este templo por el obispo Genadio a doce de las calendas de diciembre (913).»

Desde mi punto de vista, el documento resulta especialmente interesante por cuanto informa de dos circunstancias fundamentales acerca del fenómeno «mozárabe»:

a) El explícito reconocimiento de ese carácter utilitario de la arquitectura mozárabe, que citaba al comienzo de estas líneas, y que en este caso se concreta en la rehabilitación de un pequeño edificio que estaba en ruinas.

b) Y el explícito reconocimiento de la participación de una mano de obra (del «pueblo») que, aunque ello entre en contradicción con la idea «repobladora» relacionada con este fenómeno, es posible interpretar en términos de población autóctona...

Desde un punto de vista cultural, los capiteles definen tres grupos: todos los del pórtico menos uno (figuras 16 y 17), los exentos reutilizados del interior (figuras 13,14 y 15 ) y el resto (figura 29,30 y 31 ).

Los capiteles del pórtico ${ }^{34}$ junto con los de Peñalba y Lebeña, integran el modelo que he denominado "corintio astorgano», con una estructura que se fundamenta en el collarino laureado, dos coronas de hojas, caulículos, cáliz mínimo, dobles volutas, cálato troncocónico, cartelas lisas y ábaco articulado de manera peculiar, mediante segmentos angulares y siempre con el frente liso. De manera que, a partir de estas cualidades y a salvo de alguna pieza excepcional, las diferencias que hay de unos grupos a otros responden a las soluciones ornamentales y, todo lo más, al carácter de los caulículos. La mayoría — que no todos- son entregos, con una configuración que tampoco tiene precedentes entre los otros capiteles de similar naturaleza que conocemos en España, ya sean califales, ya sean de otra procedencia cultural, toda vez que la pie-

${ }^{33}$ Algunos comentarios «antiguos» son muy curiosos. Morales, Ambrosio, p. 59: «Priorato à presentación de S.M. con más de quatrocientos ducados de renta: debe ser reedificación, y nueva Dotación Real, porque en lo antiguo fundación es de un Abad, que vino de Córdoba, como parece por una piedra. No hay Reliquias, ni libros, ni y puedo decir mas de lo que tuve por relación, yo no fui allá. Las columnas de la Iglesia son lindos jaspes». Cuadrado, p. 377: «En los doce arcos de su pórtico, sostenidos por columnas sin base con capiteles de la primera época bizantina, sorprende hallar la curva reentrante o de herradura tan graciosa y tan pronunciada como si a orillas del Guadalquivir la trazaran artífices sarracenos...»

${ }^{34}$ Fontaine, 1978, p. 57 realiza una referencia a los capiteles del pórtico como síntesis entre los modelos bizantinos y las «técnicas rigurosas del sur». Esas "técnicas rigurosas del sur» deben ser una alusión al uso del trépano que, por cierto, nada tiene que ver con los trépanos de las piezas andalusíes. 
za entrega final no es el resultado de "seccionar» un capitel completo, sino de una organización que rompe la simetría del conjunto ${ }^{35}$.

Respecto de lo ya visto en las series de Mazote, hay que hacer notar que nos hallamos ante capiteles que, a pesar de su manifiesta caracterización, presentan ciertas relaciones con algunos de aquella iglesia; en concreto, la configuración de las volutas, el fragmento de cálato y, sobre todo, las cartelas son de una proximidad manifiesta. Ello y el hecho de que también aquí nos hallemos ante situación arquitectónica anómala ${ }^{36}$, de nuevo, nos asegura la reutilización de unos capiteles que, en algunos casos, tal vez estuvieran pensados para soportar cimacios más convencionales que los de Mazote, del tipo que vemos sobre los de la parte occidental y sobre el LME21 (figura 16), de entre los orientales. Dicho de otro modo: resulta evidente que todos estos capiteles fueron concebidos para integrarse en un sistema constructivo muy dependiente de los modelos orientales del Bajo Imperio.

Sus proporciones entre ancho y alto, oscilan entre 1 y 1,20 , con un caso anómalo en el que ese valor llega a 1,30; de manera que tampoco en esta cualidad existe paralelo con los modelos hispanoislámicos (califales), cuyos capiteles se someten al canon cúbico.

Frente a otros capiteles de ubicación cultural semejante, las series de Escalada se cualifican también por una técnica de talla que permanece dentro de lo que veíamos en el capitel de Bamba, es decir, mediante un relieve biselado de poquísima profundidad —en las piezas de mayor profundidad apenas se alcanzan los $10 \mathrm{~mm}$., mientras que, por lo general, esta dimensión oscila entre los 3 y los 5 milímetros-al que se añaden puntos de trépano, realizados mediante herramientas peculiares, de cabeza cónica, en ocasiones, afiladísima, cuyos diámetros oscilan entre los 2 milímetros, que se usan, sobre todo, para marcar los ejes del collarino, y los 7 milímetros, utilizados para marcar las digitaciones anulares de las hojas y otros detalles ornamentales. He aquí otro dato de singular interés para ubicar culturalmente estos capiteles, porque no conozco capitel andalusí - califal o emiral-que testifique el uso de herramientas de sofisticación comparable a las aquí documentadas ${ }^{37}$, que, sin embargo, encajan perfectamente con las posibilidades técnicas que acreditan los relieves bizantinos.

Atendiendo a los paralelos estructurales de estos capiteles y entre lo más antiguo, cabe destacar un capitel de la llamada «Casa del Perro» (Thouvenot, 1970), que posee dos filas de hojas con elementos comparables a los de Escalada. Más claro y menos forzado es el paralelismo con los del Santo Sepulcro, donde se utilizaron capiteles corintios con volutas muy clásicas, ábaco delgado, sin espata ni pedúnculo. También es claro el paralelismo con los capiteles del Convento Rojo (Severin, 1981), realizados antes del siglo V, con vueltas de hoja prácticamente idénticas a las de Escalada, y con los de la iglesia sur de Bawit (Torp, 1970, pp. 35-41: láms. 32, 2 y 3) que con una talla comparable a la que muestran aquellas, presentan una «interpretación» del orden muy similar a la que acreditan los de las tierras leonesas; y como es normal entre los siglos V y VI, con collarino que en éstos de Egipto adopta el mode-

${ }^{35}$ Los capiteles entregos califales adquieren diferentes configuraciones, pero ninguno semejante a la de éstos. Existen piezas estructuradas por completo, pero sólo talladas con ataurique en las partes visibles; también conocemos piezas que las partes ocultas tan sólo aparecen desbastadas y, por fin, otras de carácter de «chapado», es decir, talladas sobre un fragmento.

${ }^{36}$ Los cimacios son de muy distinta hechura; algunos de los capiteles del pórtido fueron concebidos para estar exentos y, por lo general, los fustes no se amoldan a los diámetros de los cestos.

37 Los capiteles cordobeses del siglo $\mathrm{x}$ documentan trépanos de cabeza cilíndrica. 
lo del contario ${ }^{3 x}$. En Aquileia hallamos otro grupo de piezas de estructura comparable a los de las tierras leonesas, siempre en los alrededores del siglo VI (Buchwald, 1966, capiteles 68 a 71, todos ellos del siglo VI). Así, el capitel de la Basílica Patriarcal (Tavano, 1978, p. 531, figura 22) (550), presenta con hojas de talla a bisel pero con abundancia de trépano; dos coronas de hojas y collarino trabajado. En Rávena (Tavano, 1978, pp. 510-511, figura 4), existen capiteles comparables, por ejemplo, en la iglesia del S. Spirito (finales del siglo V, principios del VI); también hay uno de similar estructura en la Basílica Patriarcal de Aquileia, pero con dobles cauliculos, cálato y ábaco menos articulados y tres coronas de hojas (Farioli, 969, p. 21: n." 11, n." 12). Existe un capitel de estructura muy semejante a los de Escalada en el oratorio de Santa Maria in Valle (Cividale del Friuli), de cronología muy discutida, pero que probablemente fue realizado entre finales del siglo V, y principios del VI. Algo similar sucede con el capitel del claustro de S. Salvatore, de Brescia (Verzone, 1953, pp. 87-97, figura 16), con dos coronas de hojas y volutas dobles, atribuido por Verzone al siglo VII, y por Panazza y Tagliaferri (1966, n. ${ }^{\circ} 172$, p. 135) al VI, en el que advertimos el uso de biseles, collarino con banda lisa y también, una interpretación del orden paralela a lo que hay en Escalada. Por fin, en Jerusalén (Kautsch; 317 a 331) hallamos capiteles que, dotados de cierta individualidad formal, presentan cierto «aire estructural» que también hace pensar en los de Escalada ${ }^{39}$.

Por lo que se refiere a la decoración y dejando a un lado los «acantos» de hojas afiladas, de las que ya he hablado en las series de Mazote, las palmetas que hallamos en Escalada y, sobre todo, las de foliación descendente ${ }^{41}$, cuentan con paralelos abundantísimos en todo el ámbito de influencia cultural bizantina ${ }^{41}$. Así, hallamos fórmulas totalmente homólogas en San Juan de Constantinopla, en Santa Sofía, en la Roseta de Tesifonte (V-VI) y en Siria, pero con una con-

${ }_{3 k}$ Ver también Raspi Serra, 1972, p. 141 y fig. 27, capitel del Museo Copto de El Cairo, procedente de Saqqarah, siglo vı: ábaco, tal vez, semejante a los de la serie mozarábe. Ver también Beckwith, 1963: capiteles coptos, fig. 79-84. Walters, 1974, pp. 176-185: capiteles coptos derivados del orden corintio: con cáliz, volutas reducidas, acantos afilados, de Saqqara; otros sin volutas (volutas vegetales); otros, sólo con volutas angulares (Saqqara); cesto con ábaco articulado (Saqqara). También, Grabar, 1980 (1.a ed., 1966), pieza de Saqqarah (fig. 304$)$, Museo Copto $(0,38 \times 0,32)$, con ábaco articulado comparable a los mozárabes; collarino mediante contario 1-3; orden muy alejado del corintio (sin hojas).

${ }^{39}$ Dado el carácter cultural de las series de influjo bizantino y dada la situación histórica de estos años, sería iluso pretender hallar paralelismos totales. De todas formas, las coincidencias con estas piezas mencionadas de Jerusalén van mucho más allá de lo accidental: los «acantos» derivan directamente de las variedades del corintio asiático, tienen dobles volutas, carecen de cáliz, el frente del ábaco y las cartelas son muy delgadas; de manera que parecen pensadas para integrarse en una articulación arquitectónica muy similar a la de los capiteles de Escalada o los mejores de Mazote. Algo más forzado es el paralelismo con los capiteles de Siria publicados por Tchalenko, G.: Villages Antiques de la Syrie du Nord, París, 1953, lám. LIX, capitel de Brad, con talla de biseles y cierta relación con los de Escalada. Noack (Noack, 1991, Coloquio, pp. 40-41 y lám. III, f) recoge un capitel del siglo VI, de Jerusalén, que resulta otro magnífico ejemplo de lo que estoy comentando.

${ }^{40}$ Hernández, 1930, p. 47, fig. 37, publicó un «proceso evolutivo» de las hojas de medias palmas invertidas y adosadas que, pasando por estos capiteles, culminaría en Vilanova y Cornellá.

${ }^{41}$ En relación a esta fusión de «medias palmetas», hay que señalar que hallamos la misma idea compositiva, aunque con fórmulas ornamentales distintas en un fragmento de capitel, procedente de Sta. María Aurora, de Milán, que Beloni supuso de los siglos IV-V (probablemente sea algo posterior), y en otro -netamente bizantino- de Tomis (Barnea, 1969, fig. 3,5). 
cepción algo más evolucionada que en Escalada; en San Ambrosio de Milán; en un disco de orfebrería del Museo del Bardo, procedente de Cartago y fechado en el siglo V; también en Aquileia (CSA, Aquileia, figura 239, siglo VI-VIII, p. 168); en el Norte de Africa (Duval, 1971, p. 276, figura 315), en la cornisa de la basílica II (de Vitalis) de Sbeitla; en la cripta abadial de Nonantola (Gandolfo, 1977, p. 5-39), etc, etc. Son, en suma, piezas que podemos interpretar como versión «local» evolucionada de los capiteles corintios asiáticos ${ }^{42}$.

Dejando a un lado los parentescos formales y estructurales citados, siempre de carácter «puntual», como ya señalara Gómez Moreno, no se encuentra ningún paralelo literal a estas piezas ni en Oriente ni en Occidente, de manera que también en este caso podemos hablar de una fuerte aportación local, similar a la que señalábamos para el caso de las series de Mazote: de nuevo nos hallamos ante piezas «originales», pero vinculadas directamente a las fórmulas de la cultura emisora, de manera que, tal y como se viene admitiendo y, desde mi punto de vista, estamos ante capiteles directamente emparentados con los más «bizantinos» de Mazote, que debieron ser realizados en una secuencia cronológica relativamente corta.

En cualquier caso, el especial carácter del resto de los capiteles de Escalada, permite resolver y contrastar con facilidad el problema de la atribución cronológica de todas estas piezas, porque, frente a lo que ocurriera en Mazote, en esta iglesia sí existen piezas que necesariamente debieron ser realizadas al efecto (al menos, las de las pilastras) y que, aceptando la fecha de construcción de la iglesia proporcionada por las fuentes epigráficas (913), nos permite extraer conclusiones acerca de las fases de cultura material que reflejan todas ellas:

a) La de los capiteles mencionados, sin ninguna duda, reutilizados y procedentes, bien de la pequeña edificación anterior citada por la inscripción o de alguna otra de las proximidades ${ }^{43}$.

b) La de las pilastras y los capiteles comparables, de concepción más burda y simplificada (degenerada), que resulta obligado situar hacia el año 913.

c) La de los capiteles reutilizados del interior, que determinan una secuencia cronológica de cierta amplitud.

A la vista de estos tres grupos de piezas, resulta insostenible la adjudicación a la misma fase cultural (al siglo $\mathrm{X}$ ) de las dos primeras series, por las siguientes razones:

1. La manifiesta reutilización de los capiteles del pórtico.

2. La existencia de un capitel del grupo b) en el pórtico, que parece informar del agotamiento del material de acarreo y de un intento burdo por imitar la configuración de aquellos.

3. No parece razonable que quienes podían realizar capiteles de la serie a), los reservaran para la parte menos noble de la iglesia.

4. La colocación «tardía» de los capiteles del grupo a), parece fruto de un acarreo realizado cuando no existiera premura por finalizar la construcción de la primera iglesia.

5. La manifiesta relación existe entre los capiteles de la serie b), con los asturianos tardíos, que encaja perfectamente con los datos epigráficos, por cuanto ese «pueblo», partícipe de las

${ }^{42}$ Entre los capiteles corintios asiáticos más evolucionados existen capiteles asombrosamente próximos, sobre todo, a los orientales de Escalada; ver, por ejemplo, los capiteles del pleno Imperio de Palmira (Filarska, 1966, p. 123, figs. 1 y 2) y entre los más evolucionados, aún muy cerca de lo que vivimos en Bamba, el capitel de Ahnas, del Museo Copto de El Cairo (Severin, 1981, p. 316, fig. 1).

${ }^{43}$ La existencia de dos familias ornamentales de capiteles permite imaginar que, de hecho, se trata de capiteles realizados en origen para dos edificaciones de diferente concepción modular. 
concepciones culturales de la sociedad astur-leonesa, sería el responsable de la talla de estas piezas.

6. Y a la vista de los datos suministrados por su excavación y de acuerdo con los puntos anteriores, es muy posible que sólo algunos de los capiteles reutilizados del interior pudieran pertenecer a la iglesia primitiva: el LME08 (figura 15), posiblemente del siglo VII, muy parecido a otro de la catedral de Oviedo (ACA05); el LME07 (figura 13) y el LME14 (figura 14), de hojas lisas y estructura muy dependiente de los modelos helenísticos, que pueden ser algo anteriores ${ }^{44}$.

En suma, el carácter de la inscripción y el hecho de que la iglesia fuera realizada en un momento tan temprano como el año 913, convierten a San Miguel de Escalada en «pieza clave» para resolver el problema que nos ocupa, puesto que en ella hallamos documentada toda la secuencia material asociada al fenómeno mozárabe, con la reutilización de piezas, que van desde antes del siglo VI hasta el siglo VII, y con la talla de otras realizadas al efecto, que enlazan con los precedentes asturianos. Dicho de otro modo: las cualidades formales de la escultura ornaimental, que fue realizada coincidiendo con la construcción de la iglesia, no expresan influjo andalusí. Por el contrario, en consonancia con la distribución del trabajo en aquellos años, esos elementos dan continuidad a la escultura arquitectónica asturiana y, por lo tanto, tal y como anticipábamos en el epígrafe introductorio, en este caso, sería más apropiado hablar de restos culturales «astur-leoneses», o si se prefiere, «de repoblación» ${ }^{45}$.

\section{D) Santiago de Peñalba}

Hasta ahora se viene suponiendo que la construcción de Santiago de Peñalba obedece a una iniciativa de Genadio, quien en su testamento, fechado en el año 919, dejó escrito (Gómez Moreno, 1919, p. 224 y nota 1): «Desplegando toda mi solicitud y todo mi ingenio sobre el yermo susodicho, amplié erigí cuanto mejor pude la iglesia de San Pedro, que había restaurado poco antes, transformándola con admirables edificaciones. Después construí en aquellos mismos montes un claustro, bajo la advocación de San Andrés, y otro monasterio según orden monástico; separado un trecho, construí en memoria de Santiago un tercer monasterio, que se llama Peñalba, y entre uno y otro, en el lugar que se dice Silencio, fabriqué un cuarto oratorio en honor

${ }_{44}$ El LME08 es un capitel que, como el ACA05, parece fruto del desarrollo «degenerativo" de la tradición de los capiteles de collarino laureado, que también hallamos en Santa Cristiana de Lena, y de ahí su más que posible cronología hacia el siglo vII, que concuerda con la manifiesta reutilización de estos últimos. En cambio, los otros dos (LME07 y LME14) son pseudocorintios de volutas angulares, con el cálato perfectamente marcado y, por lo tanto, con presentar ciertas cualidades orientalizantes, acaso indiquen una fase cultural anterior, relativamente singularizada respecto del flujo bizantino que nos ocupa (siglos V-VI).

45 Siempre, claro está, entendiendo esa «repoblación» como un hecho administrativo, con aportaciones mozárabes de carácter superestructural, que se traducirán en una concepción arquitectónica sujeta a los ritos practicados por las comunidades emigradas y realizada según fórmulas andalusíes. Fórmulas andalusíes que, a mi modo de ver, más que en cuestiones formales, se concretaría en estructuras comparables a la de la mezquita de Córdoba: columnas, muretes sustentantes de mampuesto, cubierta de madera, etc. y todo ello, realizado desde los criterios de utilitarismo que implica la reutilización de cuantos elementos arquitectónicos (fustes, capiteles, cimacios) se adecuaran a la funcionalidad perseguida. 
de Santo Tomás». Sin embargo, como esa cronología resultaba inviable desde el punto de vista del desarrollo formal y a la vista del testamento de Salomón (931-951) ${ }^{46}$, Gómez Moreno dedujo que. en realidad, la construcción del edificio habría sido finalizada bajo Fortis, esto es, entre los años 919 y 937. Momento que resolvía el problema forzando sus términos pero que resultaba satisfactorio desde la secuencia cultural manejada ${ }^{47}$. naturalmente, siempre con la inconveniencia del fantasmagórico influjo bizantino ${ }^{+x}$.

Desde mi punto de vista, el testamento de Genadio informa del carácter de buena parte de los documentos de esta época, seguramente inclinados hacia una matizada exageración, que también aparece en San Miguel de Escalada y en los problemáticos textos asturianos y que impone una cierta prevención a la hora de admitir sus datos. Porque, en efecto, si hacemos caso a Genadio, toda la secuencia cronológica defendida por Gómez Moreno carecería de fundamento, a no ser que retrasáramos la realización de Escalada, lo que aún resultaría más increíble. En suma, desde las hipótesis tradicionales, las fuentes documentales de Peñalba y de Escalada resultan contradictorias. Sin embargo, desde las aquí manejadas, esos problemas dejan de tener sentido sobre todo si, como en este caso, también tenemos testimonios literarios de la época de san Fructuoso que informan de una importante actividad monacal y cenobial en esta zona.

d.1) Grupo SPE1. Santiago de Peñalba contiene uno de los dos grupos que, al parecer, han llegado a nuestros días en su contexto arquitectónico. Son nueve piezas (figura 18), todas ellas entregas ${ }^{49}$ menos una, colocada en la puerta de acceso. Por lo demás, poseen collarino laurea-

th Gómez Moreno, 1919, p. 226: «empezamos y concluimos en aquel sitio, cuanto la piedad del Señor otorgó y ahora aparece».

47 Si la iglesia de Peñalba fue construida antes del 919, resultaría increíble que la de Escalada (sin el pórtico) fuera realizada en el año 913 , según procedimientos mucho más burdos, y el pórtico, con posterioridad a la muerte de Genadio, teniendo en cuenta que todas estas iglesias parecen obra de un único taIler.

4k De nuevo merece la pena leer a Gómez Moreno, en Arte árabe, p. 369: «... en Santiago de Peñalba y Sta. María de Lebeña, erigidas a las puertas de Asturias, un cierto bizantinismo triunfa; en Castilla, con San Millán de la Cogolla y San Baudel de Berlanga, lo califal toma carta de naturaleza sin perder originalidad, $y$ un pujante arte decorativo de cepa bizantina contribuye a fijar el rumbo extraeuropeo nuestro de entonces». Gómez Moreno, 1919, pp. 380-381: «... Fundóla el obispo de Astorga Salomón y fue concluida en 937, bajo la inspección de su predecesor Genadio, retirado de su diócesis en el monasterio vecino de San Pedro de Montes (....), respecto de las columnas huelga decir que son del tipo referido y hechas de mármol blanco». Ver también Fontaine, 1978, p. 120 y ss. y Luengo y Martínez, 1962.

${ }^{49}$ Por su disposición en el edificio, resulta imposible apreciar cómo se ha resuelto el adosamiento de los capiteles. En todo creo importante advertir que, al parecer, los capiteles de Peñalba no responden al sistema documentado por el resto de los capiteles de la serie leonesa en este sentido. Esta circunstancia permitiría considerar la hipótesis de que, también en este caso, nos hallemos ante un proceso de reutilización que, en este caso, alcanzaría también a los fustes y los cimacios. No obstante, debo confesar que, a mi juicio, resulta difícil admitir esta posibilidad, porque si así fuera, ello presupondría la existencia de un edificio muy bien conservado en las inmediaciones (del que se traerían los elementos arquitectónicos) que, en las condiciones administrativas del siglo $\mathrm{x}$, habría resultado más adecuado para proceder a la rehabilitación mozárabe. Lo más factible es que, a propósito del adosamiento, en esta iglesia de Peñalba se aplicara una solución distinta de la que reflejan el resto de los capiteles de «collarino laureado». El problema del alfiz nos remite a lo que ya anunciaba en las líneas anteriores. Si, como supongo, Santiago de Peñalba fue realizada en el siglo vı, habría que replantear el sentido del flujo asociado a ese elemento arquitectónico. 


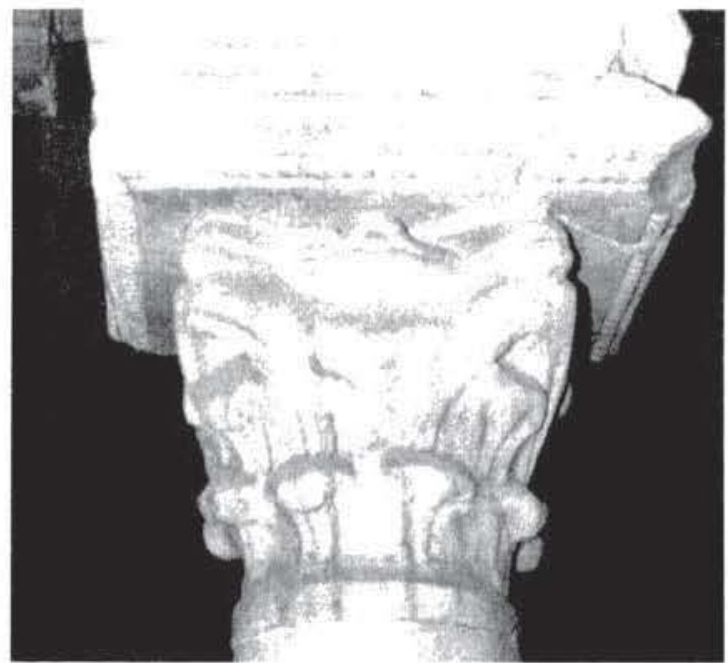

Figura 13,-San Miguel de Escalada (LME07)

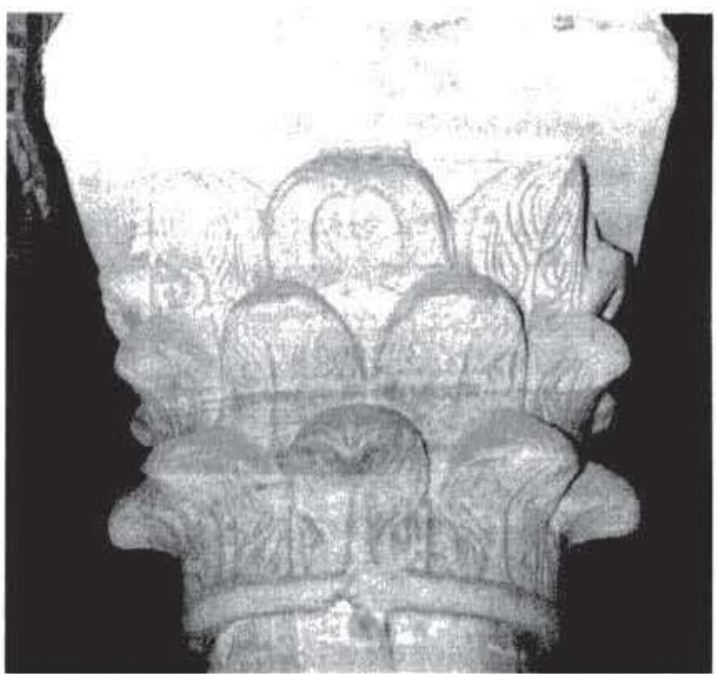

Figura 15. - San Miguel de Escalada (L.ME()8).

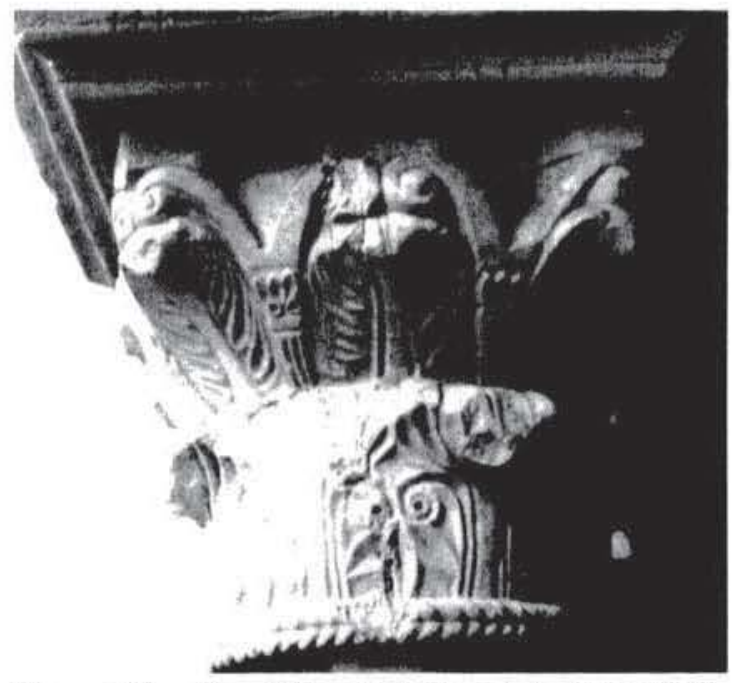

Figura 17.- San Miguel de Escalada (LME32).

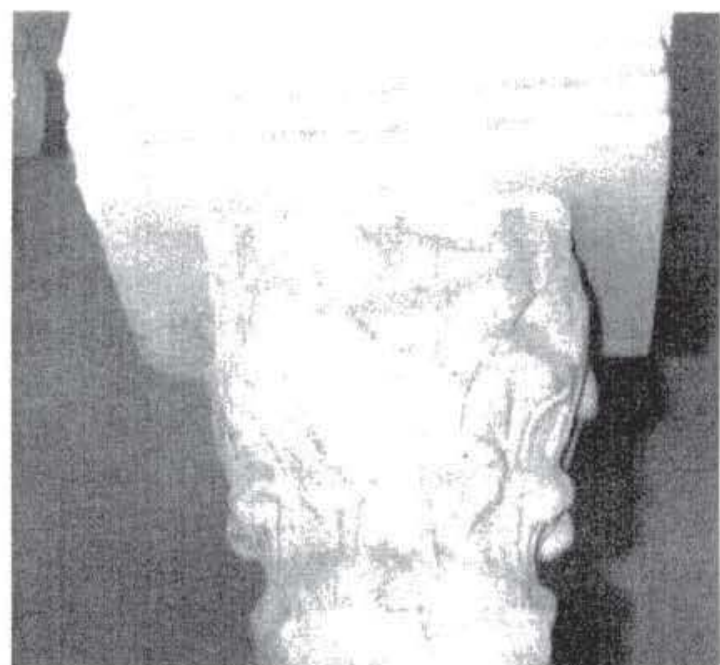

Figura 14.- San Miguel de Escalada (L.ME 14).

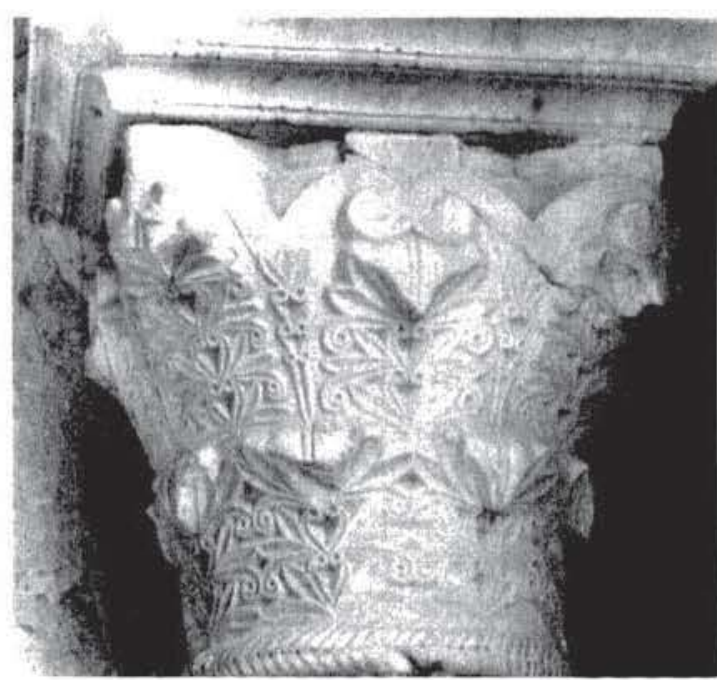

Figura 16.- San Miguel de Escalada (LME21).

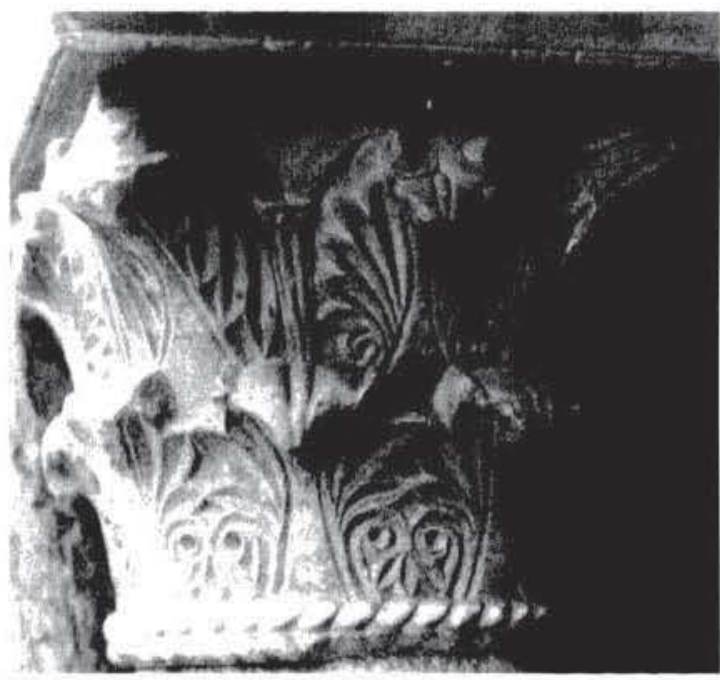

Figura 18. - Santiago de Peñalba (LSP09). 
do, cesto levemente cónico, una sola corona de hojas, cuatro más centradas bajo las cartelas, otras cuatro angulares, caulículos, dobles volutas, cálato visible y ábaco con sectores circulares; se distinguen de los de Escalada porque carecen de la disminuida referencia al cáliz que había en aquellos ${ }^{50}$.

Las hojas se agrupan según tres modelos diferentes: el adoptado en el segundo nivel, en siete de los casos, compuesto por dos medias palmetas de tres limbos rectos y uno curvado, y dos más con cuatro digitaciones rectas; el del piso bajo, similar al anterior pero con la inclusión de tres foliolos lanceolados en la unión de cada hoja con la inmediata; y, por fin, el modelo de los ángulos, basado en dos medias palmas descendentes de más de cuatro foliolos. Los caulículos, sensiblemente iguales, poseen cuatro listeles rematados en punta. Por encima de ellos, las boquillas acostumbran a resolverse según sencillos segmentos lisos; sólo en algún caso aislado existe una diminuta banda laureada intercalada entre los caulículos y el mencionado segmento. Esta homogeneidad formal casi absoluta, se prolonga a las proporciones entre ancho y alto que en todos los casos se aproxima muy considerablemente al valor $1,2(6 / 5)$, de indudable carácter clásico. Aquellos sobre los que fue posible documentar las cualidades técnicas - los de la puerta - fueron tallados mediante procedimientos similares a los de Escalada, con brocas de cabeza cónica cuyo diámetro máximo oscila en torno a los 8-9 milímetros y la profundidad de «ataque» fue de unos 5 milímetros.

Atendiendo a sus cualidades formales, sin entrar en reiteraciones necesarias y en relación a las series de Escalada hay que hacer notar que, por la carencia de cáliz, las piezas de Peñalba son un punto más evolucionadas. Contra lo que sucede en Escalada y en Mazote, y al igual que sucede en Lebeña, aquí existe correspondencia perfecta entre fustes, capiteles y cimacios: los capiteles adosados están pegados a los muros, los collarinos cumplen su función de «elemento separador» en perfecta concordancia —el diámetro del cesto por encima del collarino coincide sensiblemente con el diámetro del fuste- ; y los cimacios se ajustan con total precisión a los ábacos. En definitiva, entiendo que nos hallamos ante el primer "paradigma» de los modelos arquitectónicos para los que fueron realizados la mayoría de los capiteles que estamos estudiando ${ }^{51}$, que no responden en absoluto al funcionalismo arquitectónico que caracteriza al resto de las iglesias mozárabes y que hemos relacionado con la naturaleza de la cultura material andalusí anterior a la época de Al-Hakam. Porque ese paradigma nos habla de iglesias rurales, de reducidas dimensiones (menos de 200 metros cuadrados en planta) y con una organización es-

${ }^{50}$ Gómez Moreno (1925, p. 54-55) escribió a propósito de los capiteles de Peñalba lo siguiente: ... «capiteles corintios y de tipo especial, esculpidos a biseles sus hojas y llevando consigo el soguedo astrágalo, detalle éste que muy fácilmente los caracteriza...» (...) «Respecto de las piezas marmóreas, de carácter bien a las claras bizantino, pueden creerse labradas expresamente para los edificios leoneses donde se las halla, en el segundo tercio del siglo X, a partir de Mazote, donde parecen registrarse sus prototipos. En las iglesias anteriores nunca se las halla; a lo último fueron imitadas en Lebeña y Villanova, y desaparecen luego, dejando series... en Hornija y Sahagún».Tampoco puedo estar de acuerdo con el carácter de «prototipos» que Gómez Moreno otorga a los capiteles de Mazote, porque como hemos tenido oportunidad de ver, las series de Mazote, con tener ciertas cualidades decorativas comunes con los de Escalada y Sahagún, presentan estructuras muy diferentes. Por otra parte, es muy curioso el tratamiento que Gómez Moreno otorga a los capiteles de Lebeña, al margen del «taller bizantino» (Gómez Moreno, 1919, pp.161 y 183), como «imitaciones» de las precedentes.

${ }^{31}$ Haciendo salvedad de la mayoría de los capiteles de Mazote, que por la dispersión de sus tipos nos impiden concretar modalidad arquitectónica alguna. 
tructural que tiene muy poco que ver con la arquitectura califal y mucho con los prototipos bizantinos anteriores al siglo $\mathrm{VI}^{52}$.

\section{E) Sahagún}

Los datos documentales sobre Sahagún son indirectos y, paradójicamente, aparecen vinculados a la «fundación» mozárabe (Simonet, 1983, t. II, p. 501): «En 872 el Abad Adefonso y varios monjes que vivían en el Monasterio de San Cristóbal, situado extramuros de Córdoba, en la orilla opuesta del Betis, fundaron el célebre Monasterio de Sahagún»... «Florecían estos monjes en gran virtud y devoción, cuando de improviso se arrojó sobre el Monasterio multitud de moros y con gran furia mataron a cuantos monjes encontraron, desolando el edificio (nota 2: "subsistió la iglesia, que se conservaba con culto en 964») Quiso Dios que aquel día se hallase ausente el abad, con algunos otros monjes, los cuales, oído el asesinato de sus compañeros, se retiraron a los dominios del Rey D. Alfonso. Recibiólos este ilustre monarca como embajadores del cielo; les dió para morada el antiguo y ya destruido Monasterio dedicado a los santos mártires Facundo y Primitivo, y les concedió para su mantenimiento varios pueblos y heredades....» Y siguiendo con el testimonio de Ambrosio de Morales: "Y así, un Monasterio célebre en toda España.... tuvo por primer abad y restaurador a un mozárabe cordobés, testigo de la emigración de que tratamos. El diploma de don Alfonso III, en que se refiere este suceso, lleva la fecha del año 874.» ${ }^{53}$ Luego el monasterio sería destruido... para ser reconstruido entre los años 920 y 940 (Gómez Moreno, 1919, p. 107) ${ }^{54}$ y consagrado el año 935, bajo Ramiro II (Gómez Moreno, 1919, p. 202 y ss.) ${ }^{55}$. Es decir, como en el caso de Escalada, y ahora en un momento anterior, nos encontramos con una comunidad mozárabe a la que se otorga un «antiguo y ya destruido Monasterio»...

Los capiteles relacionados con Sahagún, como en el caso de Hornija, integran un conjunto de cierta heterogeneidad; una heterogeneidad que desde la ornamentación alcanza, incluso, a la estructura de los capiteles. Si aún restara alguna duda acerca de la atribución de todo el grupo al siglo VI, bastarían estos capiteles para despejarla, porque, además de las corrientes documentadas en Peñalba y Escalada, aquí aparecen fórmulas perfectamente integradas con lo habi-

52 Contra los reparos que se han planteado a mis hipótesis, argumentando que los conflictos políticos del VI no fomentarían un ambiente apropiado a la actividad arquitectónica, cabría responder que el carácter estructural de esta iglesia, completamente abovedada y con unos muros sobredimensionados, especialmente adecuados para resistir todo tipo de agresiones, es un dato muy significativo en ese sentido, que, por el contrario, ayudarían a comprender que fuera realizada en un momento de conflictos políticos y militares.

53 Y sigue Simonet (p. 502): «es de notar, por último, que en los diplomas y privilegios concedidos por Alfonso y demás monjes fundadores del Monasterio de Sahagún, suscriben algunos personajes que por sus nombres parecen mozárabes emigrados, como Teudecuto, Arcediano de la Sede Baiecense y Recemiro Ibn December».

54 Ver Escalona, Historia del Monasterio de Sahagún, doc. XXII.

5s Gómez Moreno, 1919, p. 107: Alfonso III compra en 904 la iglesia arruinada de los Santos Facundo y Primitivo, para «que allí fundase un abad Alfonso y sus compañeros venidos de Andalucía, dando así origen al célebre monasterio de Sahagún». Sobre el «taller bizantino» (920-940), ver también pp. $143,161$. 
tual en las áreas bizantinas durante los siglos V y VI que, además, asocia esas fórmulas con los prototipos de Peñalba y Escalada. Concretamente, en el capitel del convento de Santa Cruz conviven las soluciones de Escalada con una variedad bizantina de capitel corintio de volutas exteriores que, por otra parte, nos remite al de Bamba.

Sin salirnos de lo decorativo, los capiteles de Sahagún, además de recoger algunas de las soluciones que ya hemos tenido oportunidad de ver, presentan las hojas más directamente relacionadas con el acanto asiático de los prototipos desarrollados a partir del siglo II, y en especial, con algunas piezas coptas de Saqqara ${ }^{56}$ (figuras 20 y 21 ), a las que también les une una concepción del orden semejante ${ }^{57}$. Algo parecido sucede con otros motivos como, por ejemplo, la proliferación de perlados que, del mismo modo, nos remiten a la misma tradición. Además, muchos de los miembros de esta familia presentan una proporción entre ancho y alto que oscila entre 1,17 y 1,44 , es decir, que también nos remite a fórmulas helenísticas. En definitiva, es muy probable que podamos situar en Sahagún el nexo de unión entre el capitel estrictamente bizantino de Bamba y los que, desde la misma concepción cultural, se realizan en la península Ibérica bajo el impulso de una acción creadora nueva.

e.1) Grupo $\mathrm{SAHI}$ (corintio de volutas exteriores). Entre todos los capiteles procedentes de Sahagún sólo es posible establecer un grupo, éste de volutas exteriores, que, además no se mantiene inalterable, sino que varía sustancialmente de un capitel a otro. En lo común hay que citar al collarino «laureado», dos coronas de hojas con series de foliolos rectos y uno corto encurvado, y volutas exteriores. En algunos, el contario remata el borde del cálato y, por lo general, las cartelas están muy devaluadas, llegando, incluso, a desaparecer. En un caso, tal vez, accidental, la superficie del ábaco carece de anillo y los brazos que culminan en las volutas se prolongan hasta la cruz de cartelas. Sus paralelos más próximos los hallamos en Bizancio y Egipto, atribuidos a los siglos V y VI (Kautzsch, 1936 y Grabar, 1966, figura 311); el hecho de que los de Sahagún resulten algo más evolucionados, nos permite asegurar con cierta probabilidad que, como los anteriores, fueran realizados hacia el siglo VI.

\section{F) San Román de Hornija y Toro}

También San Román de Hornija, como Bamba, conserva una tradición que le vincula con las instituciones visigodas a través de sus monarcas, en este caso y concretamente, con Chindasvinto, a quien se supone enterrado allí. Recordemos el relato de Ambrosio de Morales

56 Los foliolos alargados de los capiteles de Sahagún guardan una cierta relación con algunas series de Qalat Siman, en las que, con un tratamiento distinto hallamos la seriación de foliolos mediante una encurvada, formando círculo, y otras biseladas y alargadas. También les une, indirectamente, la concepción que la mayoría de esos capiteles sirios presentan en su peculiar interpretación del orden corintio, muy próxima a la de los capiteles tardorromanos del noroeste hispano, mediante cálices de enorme desarrollo que dejan sin sentido ornamental a las volutas. Ver Strube, 1977. Las hojas alargadas de perfil afilado nos remiten a fórmulas orientales, también espléndidamente documentadas en Baouit (Graviers, 1932) y en Siria, con la única diferencia de que en ambos casos no existen digitaciones anulares.

${ }^{57}$ Entre los paralelos es posible señalar un fragmento de arquitrabe, aparecido en el Foro de los Césares, de Roma que Pani Ermini (1974), t. II n. ${ }^{\circ}$ 30, p. 51 y tav. XIV) sitúa entre los siglos Ix y x y que, desde mi punto de vista, debe ser anterior. 


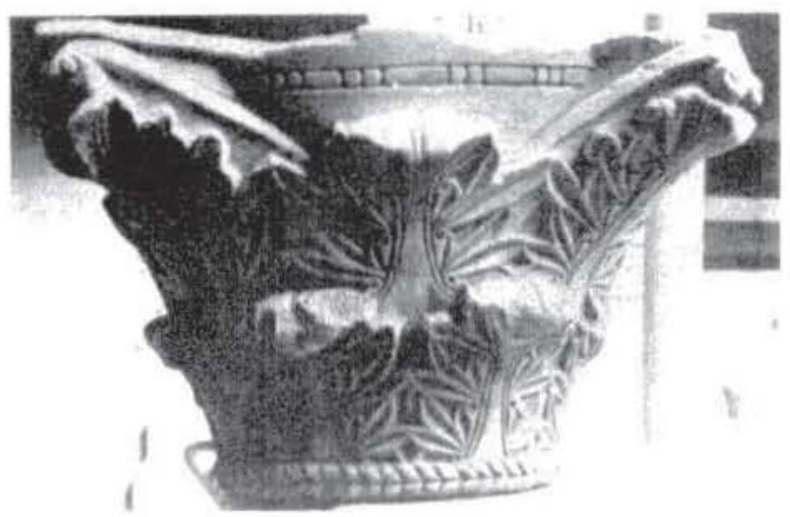

Figura 19.-León. Musco Arqueológico. Procede de Sahaguin (I.MA04).

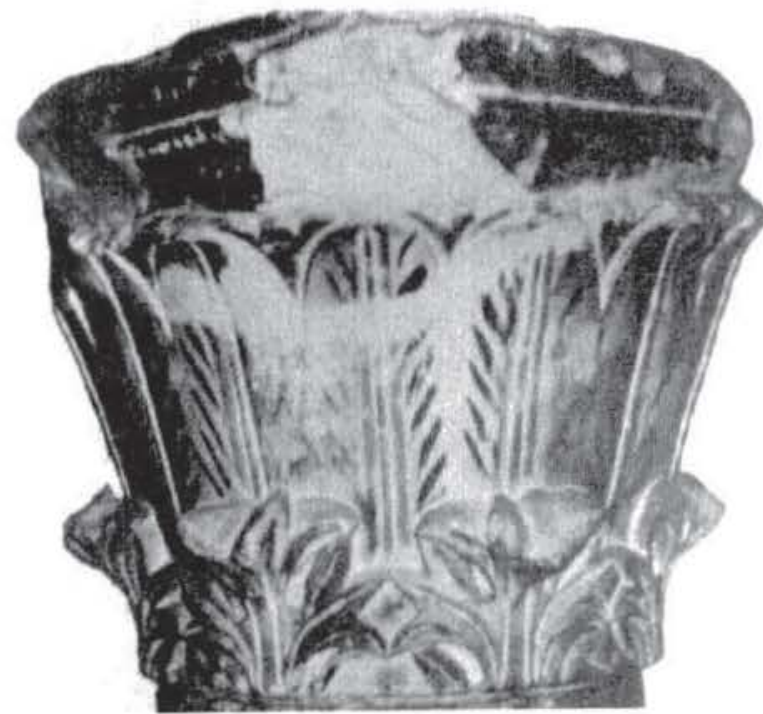

Figura 21.-Saqqara.

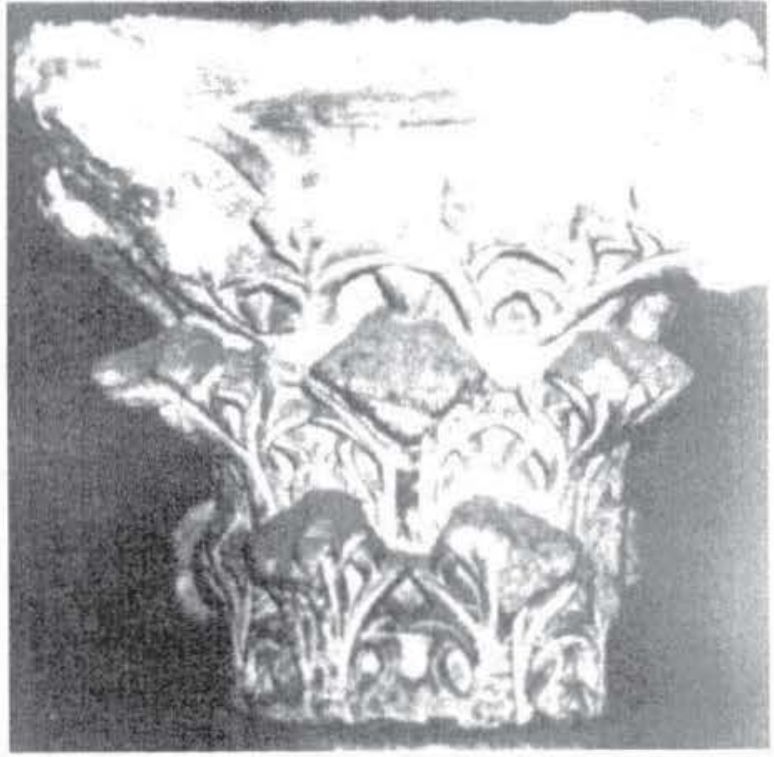

Figura 20. Siquqara.

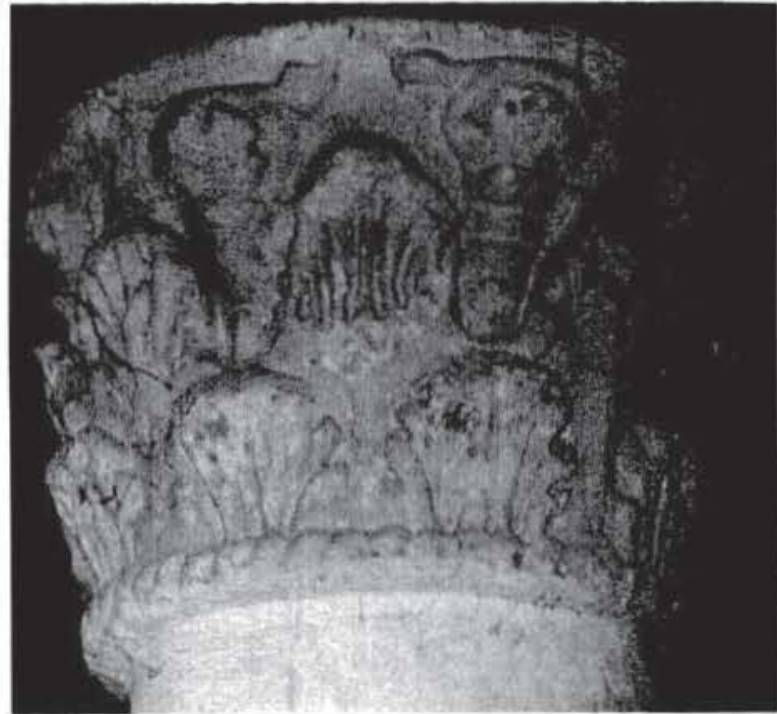

Figura 22.-Toro, Santo Tomás (ZTR02).

(p. 11): «San Román de Hornija, cerca de Toro: fundóle el rey Cindasvinto de los godos, y está allí enterrado. Aquí no dan más relación, y hay Reliquias, aunque deben ser menudas. De Fundación, ni dotación no es maravilla que no haya memoria. siendo tan antiguo aquello. El enterramiento del Rey está a un lado, con arco y reja delante. Tienenle por Santo en aquella tierra. y en el Monasterio tienen una Historia repartida en nueve liciones como para leer en Maytines, y es lástima ver qu an fingida y fabulosa es». Ni que decir tiene que el componente mítico de que nos hablara Ambrosio de Morales, de nuevo, ha de ponernos en guardia ante la más que dudosa veracidad de unos relatos, sin duda, condicionados a intereses ajenos a la reconstruc- 
ción histórica ${ }^{5 x}$. En todo caso, tampoco parece posible poner en duda la vinculación entre San Román de Hornija y Chindasvinto; una vinculación que, sin grandes problemas, muy bien pudo traducirse en que, en efecto, como recoge la tradición, dicho monarca fuera enterrado allí. Ahora abien, a partir de esta hipótesis ¿qué podemos concluir? Para R. Corzo ello permitiría explicar la aparición del foco bizantino del noroeste, de manera que todos los capiteles que estamos viendo serían la consecuencia más o menos directa de una iniciativa surgida en la época de ese rey... Se me excusará por no rebatir un argumento que, tal y como hemos visto, entra en contradicción frontal con las cualidades materiales de los capiteles de collarino «laureado». No obstante, ello no quita para que, dejando a un lado la hipótesis de Gómez Moreno, a partir de dicha tradición, podamos establecer un nuevo marco probabilístico que bascularía en torno a la polaridad determinada por el hecho de que, en realidad, bajo Chindasvinto se acometiera alguna actividad constructiva en «solar yermo", y por la posibilidad de que el mencionado rey decidiera ser enterrado en un lugar sacralizado de antiguo mediante una importante construcción religiosa, a la que muy bien pudo añadir alguna ampliación... Pero detengámonos en el análisis de los capiteles.

En San Román de Hornija ${ }^{59}$ se acentúa lo que veíamos en torno a Sahagún, porque allí encontramos el más espectacular y heterogéneo grupo de capiteles de collarino «laureado» conocido. Y si a los capiteles de Hornija unimos los hallados en sus proximidades (Toro y Morales de Toro), la variedad desborda toda fantasía e ilustra hasta dónde llegó la capacidad creativa de este interesante núcleo cultural. La variedad es tanta y tan rica que, desde mis hipótesis, resulta extremadamente difícil establecer una línea evolutiva clara. Unos son más clásicos en su comprensión del orden, pero integran modelos ornamentales muy evolucionados; otros, menos fieles a aquel carecen de innovaciones; otros, en fin, emplean ábacos de estricto sentido clásico. En suma, es como si nos halláramos ante uno o varios «talleres» —entendido como unidad productiva - dominados por un fuerte individualismo o, si se quiere, por un activo sentido creativo.

Entre ellos se encuentran algunos que sirven para jalonar la evolución y para abrir una serie de hipótesis que podrían matizar lo que estamos viendo. Concretamente, estoy pensando en los de Santo Tomás de Toro y en dos de Hornija. El primer vértice es un cesto de capitel compuesto (figura 22) muy mutilado, con hojas de fuerte plasticidad, sumamente próximo a los prototipos bajoimperiales, cuya realización no debió separarse mucho del año 400 , si es que no es an-

${ }^{58}$ Gómez Moreno (1919,p. 185), recoge estas noticias y, por supuesto, las referencias de la época de Alfonso III (891), quien cede San Román de Ornica a San Salvador de Tuñón: «En la continuación a la Historia de los reyes godos por san Isidoro, que se atribuyó de antiguo a S. Ildefonso, dícese que Chindasvinto murió... (en) 653... y que fue sepultado en el monasterio de San Román de Hornisga... que él había edificado desde sus cimientos...», pp. 186-187 también recoge el relato de Ambrosio de Morales (Viage Santo): «Yo vi la iglesia antigua, de obra gótica, con un crucero de cuatro brazos, como la describe San Ildefonso... Mas por haver después querido ensanchar la capilla mayor se ha perdido la forma de la fábrica antigua, y solo quedan muchas de las ricas columnas de diversos géneros y colores de mármoles que avía por todo el edificio», p. 189, menciona 16 capiteles (contando los de Morales y Toro): «Hay piezas... en la adjunta casa del priorato, construido en 1786?; en un molino que le pertenecí....»

59 Ver Gómez Moreno, 1927; Lampérez, p. 235, habla de capiteles ¿visigodos?; Speltz, 1959, p. 134, lám. 69-2, recoge el capitel de los pájaros de Hornija como pieza bizantina; Rollán Ortiz, p. 43-47. Sheppard, 1984, pp. 7-16: en relación a la Lapidary Collection de Torcello, frisos del siglo viII con dobles palmetas y capitel que se da cierto aire al pequeño de Hornija. 

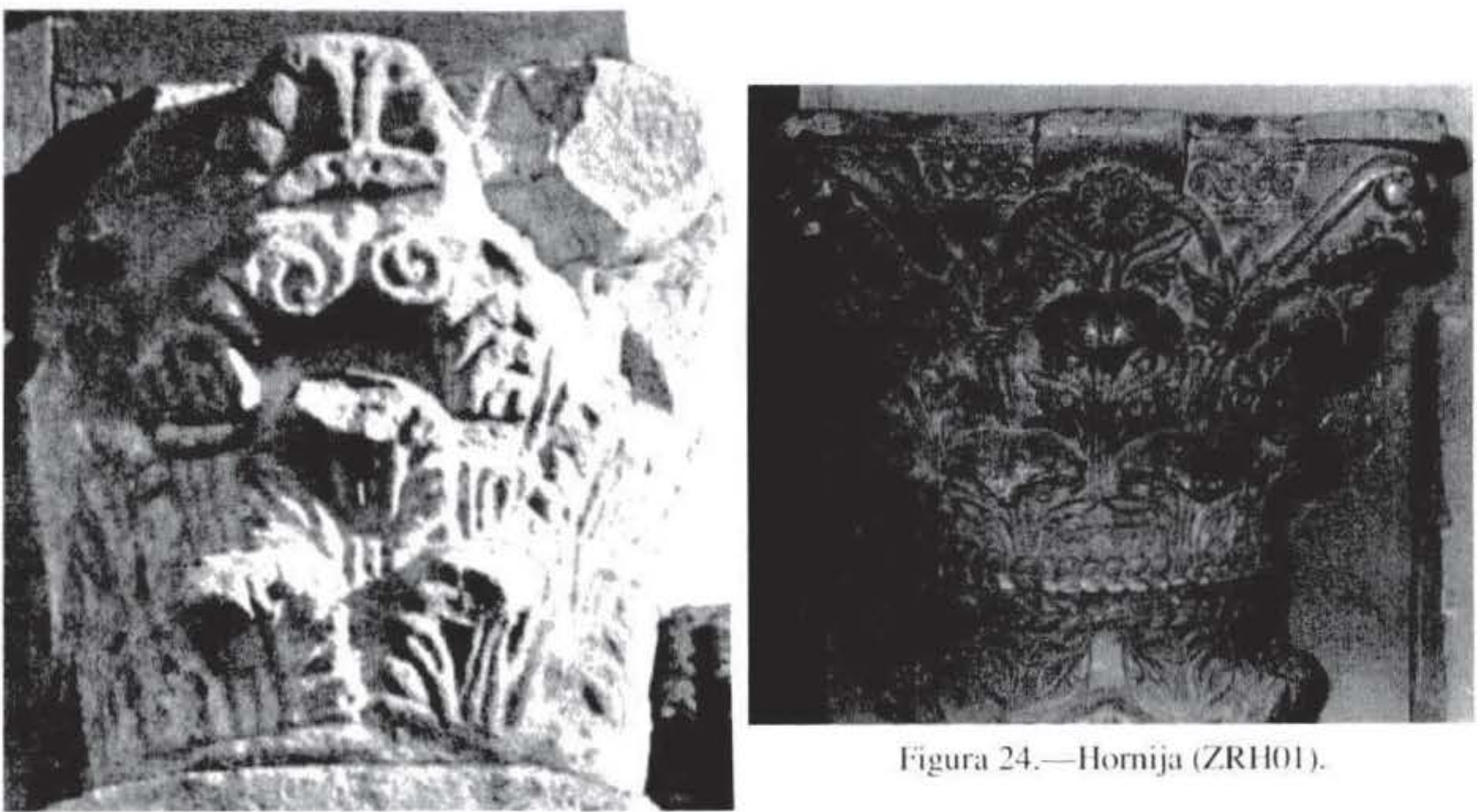

Figura 24.-Hornija (ZRHO1).

Figura 23.- Hornija (según Gómez Moreno).

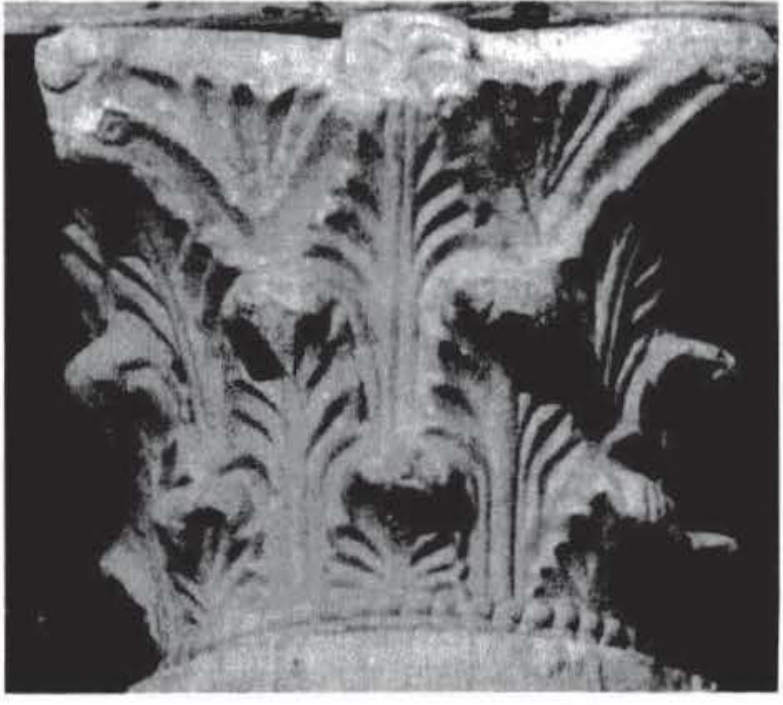

Figura 25.-Hornija (ZRH05).

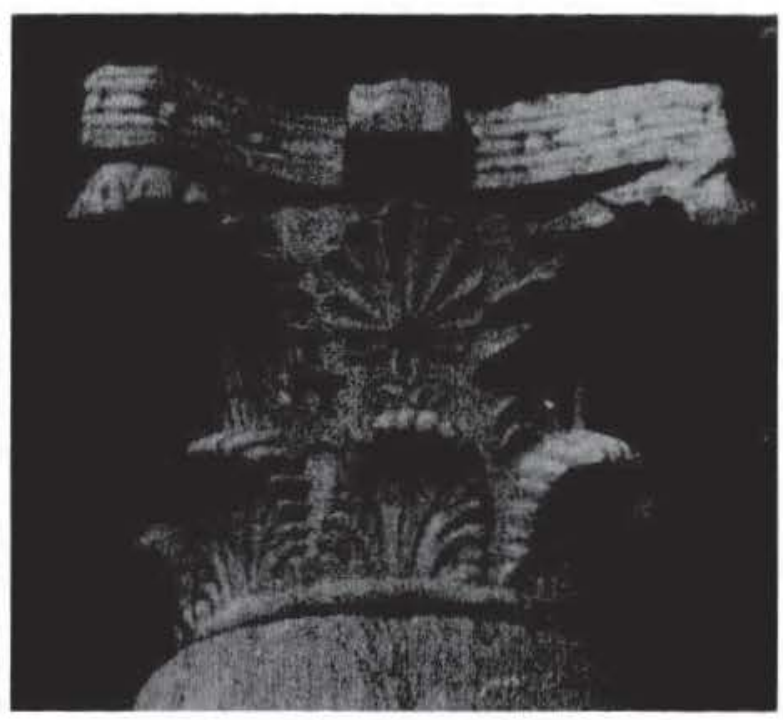

Figura 26.-Hornija (ZRH).

terior. Los otros dos son corintios clasicistas de similar cronología (figura 23$)^{60}$. En conjunto revelan la existencia de una corriente, indocumentada por otras piezas, de excepcional importancia por tratarse de la zona de que se trata, y de un sentido marcadamente «occidental» que, por lo tanto, también podría servir para explicar la aparición del collarino «laureado" al margen de las aportaciones orientales y el mantenimiento de la organicidad del orden corintio. Concretamente, el cesto de capitel compuesto posee un peculiar collarino "sogueado", que permite otor-

60) Sólo conozco estos capiteles a través de las fotografías publicadas por Gómez Moreno. 
gar cierto crédito a una tercera posibilidad para explicar la génesis del «collarino laureado», como resultado de una evolución "creativa» a partir de los collarinos lisos, que son muy frecuentes en los capiteles tardorromanos del noroeste. Y es que los otros dos capiteles mencionados de Hornija parecen reforzar esta hipótesis, toda vez que documentan la pervivencia del orden corintio asociado al collarino liso que, a su vez, permitiría comprender el rezago helenista al que me he referido con insistencia.

Por lo demás, los capiteles de Hornija que fue posible estudiar directamente muestran un repertorio de trépanos que supera por arriba y por abajo a las series de otros lugares: entre 2 y 10 milímetros de diámetro. Las proporciones entre ancho y alto, entre 1 y $1,51^{61}$, como en Sahagún, nos remiten a modelos helenistas. En el sentido decorativo, parece exclusivo de este área el uso de grandes «florones» que no llegan al extremo del ábaco y que se sustentan sobre palmetas o sobre grandes tallos nacidos, bien de los caulículos, bien por detrás de alguna hoja. También aquí es frecuente hallar trenzados de dos cabos, empleados igualmente en Italia (Roma, Milán y Véneto) durante los siglos V y VI y, después, en la arquitectura de época visigoda.

A mi juicio, pues, nos hallamos ante un conjunto de piezas que definen una secuencia cultural desarrollada entre los siglos IV y VII, con un momento de apogeo que, como en el resto de las edificaciones del mismo ciclo, habría que situar hacia el siglo VI, cuando serían realizados los capiteles más sobresalientes. Y lo que es más importante, de las cualidades de los de aquí podemos deducir la existencia de otro «taller» perfectamente individualizado.

\section{G) Santa María de Lebeña}

La iglesia que presenta algunos de los capiteles más evolucionados de la serie está documentada hacia el año 924, cuando el Conde Alfonso de Lévona y su esposa fundan y dotan la iglesia de Santa María (Gómez Moreno, 1919, p. 267 y ss.) ${ }^{62}$. Ese dato le sirvió a Gómez Moreno para deducir que sería entonces cuando se construyó la iglesia y, por supuesto, cuando se tallaron los capiteles ${ }^{63}$. En mi opinión, esa sería la fecha de rehabilitación de un edificio que, como Santiago de Peñalba, habría permanecido hasta entonces abandonado pero en aceptable estado de conservación; en un estado tan aceptable de conservación que, contra lo que, probablemente, sucediera en Mazote o en Escalada, no fue preciso tallar capitel alguno ${ }^{64}$. Y por si cu-

61 Valores originales constatados: 1,$31 ; 1,31 ; 1,51 ; 1,01 ; 1,25 ; 1,15 ; 1,17 ; 1,29 ; 1,24$. Adviértase que, contra lo que se ha dicho con cierta ligereza, no existe concentración de valores según modelos califales, ni muchísimo menos.

${ }^{62}$ Gómez Moreno, 1951, p. 378: ... «debió su erección al conde Alfonso de Lévana, tal vez mozárabe, y a su esposa Justa, de nombre andaluz conocido». Ya se comprenderá lo accidental de la hipótesis de que los Condes de Lévona fueran ellos mismos mozárabes.

${ }^{63}$ Gómez Moreno, 1919, p. 278 y lám. CVI-CVII: Capiteles: .... «pudiendo creérseles esculpidos por el mismo que hiciese los de Peñalba y pórtico de Escalada». Sin embargo, en otras ocasiones, se inclina por creerlas «imitaciones» de época posterior (G6́mez Moreno, 1925, pp. 54-55: ... «a lo último fueron imitadas - las piezas marmóreas, es decir, los capiteles-) en Lebeña y Villanova...»).

${ }^{64}$ Es muy interesante el «juicio relativo» que le supuso a Gómez Moreno el carácter de la iglesia de Lebeña. Gómez Moreno, 1951, p. 369: ... «en Santiago de Peñalba y Sta. María de Lebeña, erigidas a las puertas de Asturias, un cierto bizantinismo triunfa; en Castilla, con San Millán de la Cogolla y San Bau- 


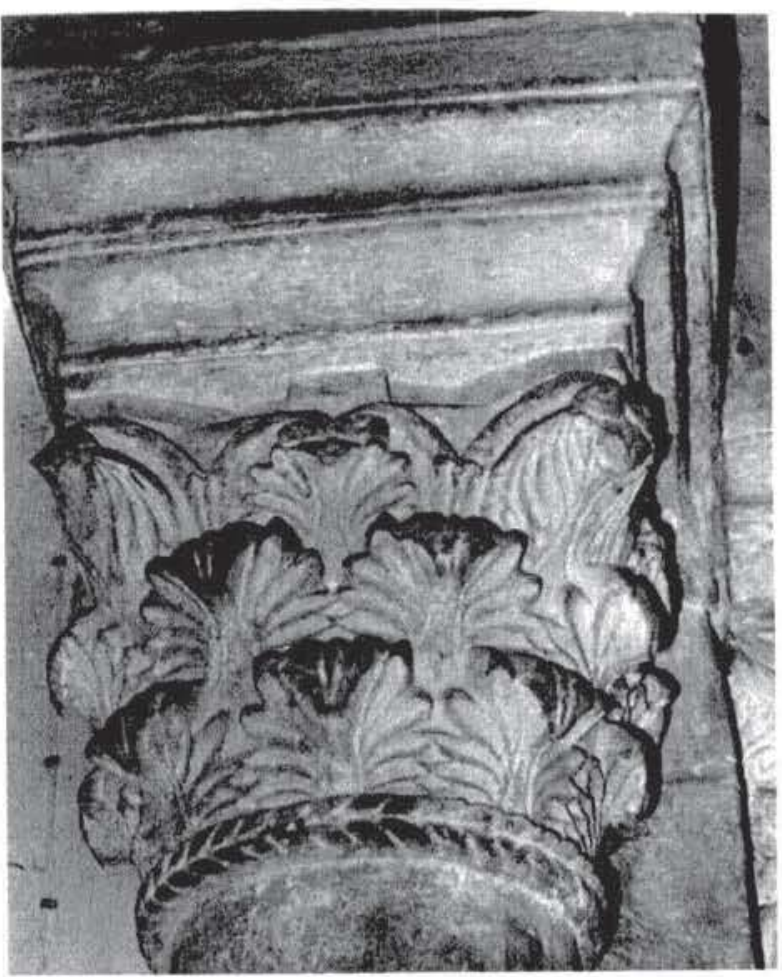

Fïgura 27.-Lebeña (SLEI1).

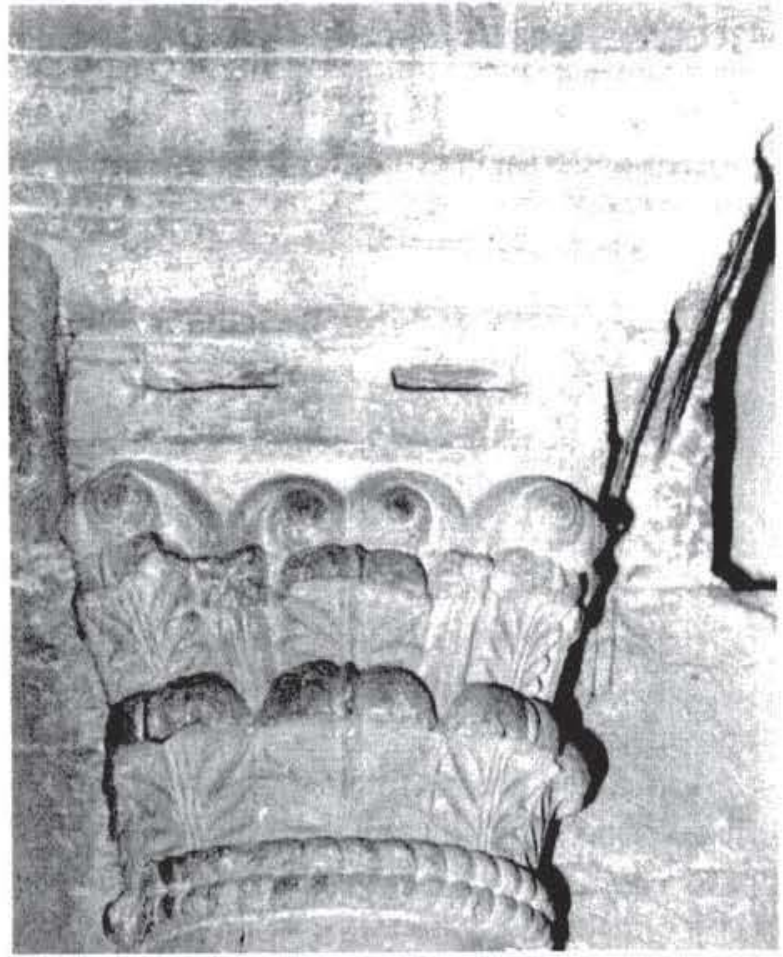

Figura 28.-Lebeña (SLEI5).

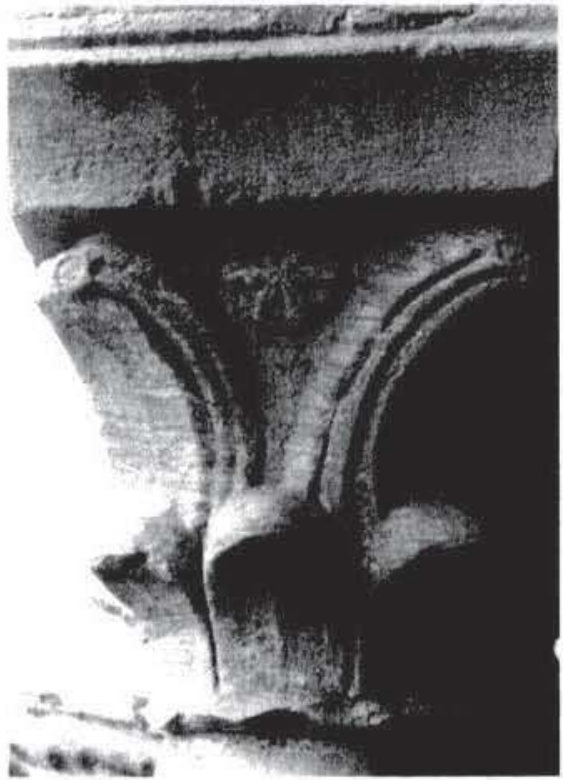

Figura 29. - Escalada (LME26).

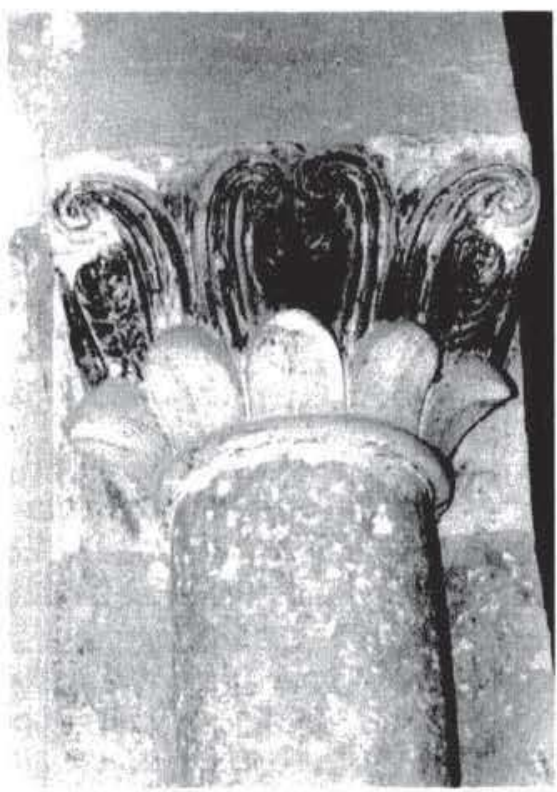

Figura 30.-Escalada (LME02).

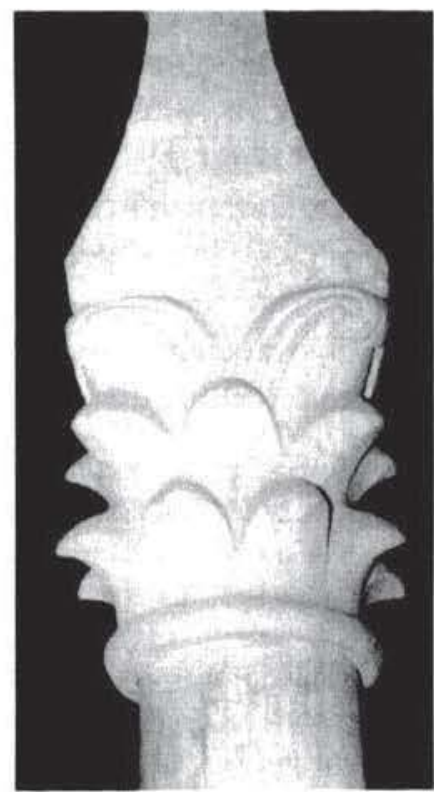

Figura 31. Escalada(LME(4). 
piera alguna duda, desde las hipótesis tradicionales, de nuevo reaparece el problema de encajar las fechas de los documentos con los restos materiales, porque ese año 924 resulta incongruente con la frontera del 930, en la que, según Gómez Moreno, fue realizada la parte occidental del pórtico de Escalada, y que presenta unos capiteles mucho más dependientes de los prototipos ornamentales bizantinos que los de Lebeña —de concepción mucho más localista-y que, por lo tanto, deberían ser posteriores a aquellos, en especial, si suponemos que todos ellos - los de Escalada, Peñalba y Lebeña- fueron obra del mismo taller ${ }^{65}$.

En Lebeña existen tres familias básicas ${ }^{66}$, de las cuales sólo una aporta novedades que trascienden lo decorativo. Las demás cuentan con el astrágalo tradicional, dos o tres pisos de hojas, caulículos, dobles volutas, cartela mínima y ábaco semejante a los de Peñalba o Escalada. La referencia al cáliz se ha minimizado o, simplemente, no existe. Los sectores de los «acantos» están cubiertos por dos modalidades fundamentales: foliolos rectos sin anulaciones, que configuran «hojas-peine» o agrupaciones de medias palmetas descendentes como las de Peñalba, pero aún más desarrolladas. Se ha eliminado casi por completo el uso del trépano con valores plásticos, que apenas se manifiesta en los «ojos» de las palmas descendentes y en algunos detalles sueltos.

En cuanto a la serie más «innovadora» (figura 28), constatamos la intervención de un «taIlista» ${ }^{67}$ que modifica algunos detalles del ábaco, las volutas y la vuelta de las hojas, de manera que no hallamos en otras piezas. También aquí, los capiteles encajan perfectamente entre fustes y cimacios, de manera que, de nuevo, hemos de deducir que, al menos, hasta la altura de estos últimos, la iglesia permanece tal y como fue concebida.

En el capítulo de los paralelos, hemos de señalar que la modalidad de las «hojas-peine» es relativamente frecuente en piezas tardohelenísticas y que los ejemplos conocidos, en este caso más que en otros, no pueden entenderse como reflejo de una relación cultural, sino como fruto de situaciones culturales comparables. Ese es, por ejemplo, el caso de algunos capiteles romanos del norte de Africa y de algunas soluciones decorativas orientales de época temprana (Filarska, sobre capiteles de Palmira, 1966, p. 122-128; sobre un capitel del museo de Trípoli, Farioli, 1969; De Angelis D'Ossat, 1975, también para un capitel norteafricano procedente de Gadames). Algunos capiteles del complejo paleocristiano de Al Khadra (Angelis d'Ossat y Farioli, 1975 , especialmente el cat. n. 30, figura 56), «degenerados» en extremo, presentan un tipo de hoja perfectamente integrable con los más evolucionados de Lebeña.

del de Berlanga, lo califal toma carta de naturaleza sin perder originalidad, y un pujante arte decorativo de cepa bizantina contribuye a fijar el rumbo extraeuropeo nuestro de entonces.»

${ }_{65}$ Cambiando el término «taller» por "corriente cultural» y como tendremos oportunidad de señalar más adelante, las cosas cambian poco. Y es que la secuencia cultural definida por los capiteles de Escalada, Peñalba, Lebeña y los que son similares a ellos, supone un proceso de integración - de «contaminación localista»-que, como señalara el propio Gómez Moreno en 1919 (p. 183) y en 1925 (pp. 54-55), culmina en Lebeña, donde están las piezas más simplificadas y, por lo tanto, más alejadas del "paradigma bizantino». Gómez Moreno «resuelve» la contradicción remitiéndose a los «prototipos» de Mazote, pero ya hemos señalado cuán artificiosa es esa explicación.

${ }^{66}$ Fontaine, J., 1978, p. 176, organiza los capiteles de Lebeña según cuatro series: 1.-7 de los 8 del cuadro central: 3 filas de hojas, borde superior en ganchillo. 2.-Arquería longitudinal de la nave: 2 filas, pico de águila. 3.-Bajo arco triunfal: 3 filas de folíolos aplanados, picos se unen. 4.-Arcos transversales (alto, alrededor de $22 \mathrm{~cm}$.) similares a la 1 con 2 hileras de hojas.

${ }^{67}$ El entrecomillado responde a la intención de matizar el término en sentido abstracto. 


\begin{tabular}{|c|c|c|c|c|c|c|c|}
\hline BAмBA & SANCBRRAN DE MZZOTE & ESCALADA & $\begin{array}{l}\text { ESCAADAY } \\
\text { PESNABAA }\end{array}$ & SAHAGLS & HORUA Y YORO & & EBEIA \\
\hline 领 & 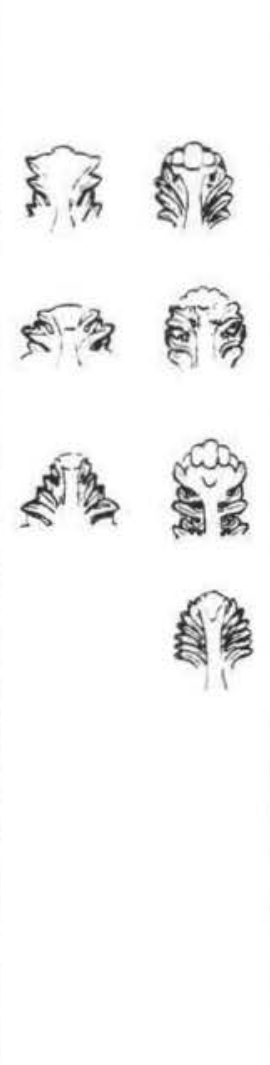 & 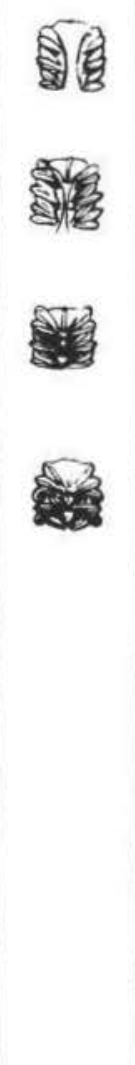 & $\widehat{a d}$ & 到 & 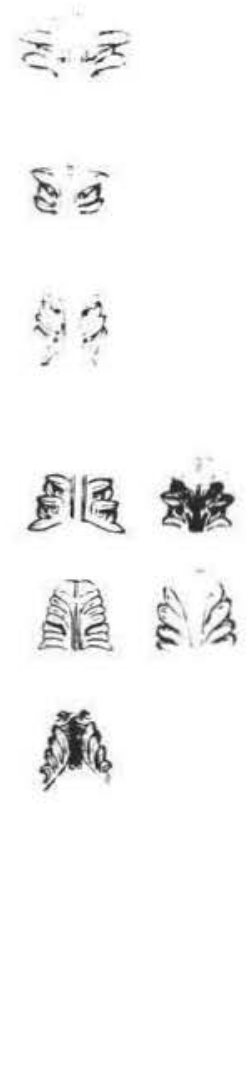 & 斯会 & हैं \\
\hline
\end{tabular}


También es posible citar algunos paralelos con las formas decorativas derivadas de la hoja de palma: entre ellos merece ser destacado un capitel derivado del orden compuesto de Santa Pressede, en Roma (Pani Ermini, 1974, T. I, n. 77, p. 131 y tav. XXXIII), de proporciones comparables a los de Lebeña (altura, 22; ancho, $19 \mathrm{~cm}$.) que la mencionada autora situa entre interrogaciones en el siglo IX y que, a juzgar por la articulación del ábaco, acaso sea anterior ${ }^{68}$.

\section{H) Otros capiteles}

Como es sabido, se conocen algunos capiteles más, procedentes de lugares situados en el mismo área geográfica que, sin embargo, han llegado a nuestros días descontextualizados y desprovistos de otros recursos documentales. De todos ellos destacan, en términos cuantitativos, cuatro de Rueda del Almirante, dos de Nava de los Caballeros y de Valdevasta; y en términos cualitativos, el de Sandoval. Todos ellos, dentro de las líneas que tenemos indicadas, parecen culminar en otras piezas de concepción diferente repartidas por el norte y noroeste peninsulares, y seguramente realizadas a partir del siglo VII, cuando el influjo bizantino había perdido vigor cultural y se había convertido en la referencia que sustancian los restos asturianos de los siglos posteriores.

\section{CONCLUSIONES GENERALES}

Nos hallamos, pues, ante restos materiales de indudables relaciones con Bizancio, dotadas de fuerte personalidad que, sin embargo, y a pesar de aparecer en el medio rural, no podemos relacionar con una impronta localista marginal, sino con un foco cultural preexistente más «helenizado» que otros del norte de Africa, que también asimilaron las corrientes bizantinas y pudieran compararse a él; lo que hemos visto nos hace pensar en un fenómeno comparable a los que sufrieron Aquileia, la Rávena en los años posteriores a Justiniano, acaso Mesina ${ }^{69}$ y, desde luego amplias zonas de Siria ${ }^{70}$. Fenómeno que podríamos sustanciar en los siguientes puntos:

\section{A) Coordenadas culturales}

Todos ellos permanecen dentro de la tradición del orden corintio, con peculiaridades que, a pesar de su carácter singular, no suponen transgresión de la idea orgánica helenista, en oposición a lo que sucede hacia el siglo $\mathrm{X}$ en otras áreas rurales de cualidades culturales comparables

${ }^{68}$ La catalogación de los restos de Sata. Pressade permanecen sujetos a debate con bandas cronológicas muy amplias: existe un capitel corintio que para Krautheimer, 1937-54, III, pp. 250-251) sería romano, mientras que para Pani Ermini sería del IX.

${ }^{69}$ Agnello, 1966 recoge una colección de capiteles de impronta bizantina que, en cierto modo, ilustran un fenómeno cultural similar al del área leonesa, con elementos decorativos de una gran originalidad.

${ }^{70}$ De ahí las persistentes relaciones que se han establecido con estos lugares y que, sin embargo, más parecen paralelismos forzados por situaciones históricas comparables. 
a las que se pueden suponer para el noroeste peninsular. Otro tanto podemos decir del repertorio ornamental empleado en ellos, así como en el resto de las cualidades que determinan el carácter global del capitel, desde su servidumbre arquitectónica hasta su dependencia respecto de las herramientas de talla, increiblemente sofisticadas para lo que podría ser una comunidad rural del siglo $\mathrm{x}$. Todo ello y la existencia de algunos capiteles sueltos de manifiesto sentido tardorromano, nos permiten concluir que el influjo bizantino del que estamos hablando se aplicó sobre una zona de cierta romanización en un momento anterior a la disolución de la tradición helenista, con resultados tan brillantes como los que hemos señalado. Entre ellos, merece ser reseñado el uso de cimacios, entre los que destacan aquellos de escaso espesor de Mazote (que no se repetirán), el collarino «laureado», la tendencia a olvidar el cáliz, el uso de una técnica de taIla peculiar, etc.

En todo caso, a juzgar por la manifiesta actividad del mencionado componente bizantino, pero, sobre todo, por la manifiesta existencia del factor «occidental», no resulta admisible que lo más sustancial del conjunto pudiera haberse realizado en el siglo VII, como propone R. Corzo, toda vez que esa hipótesis implicaría la total recomposición de la cultura de época visigoda. Si, como supone R. Corzo, Chindasvinto hizo venir artífices («artistas») bizantinos para construirse un mausoleo, no se comprenderían los componentes «occidentales» y, como planteara en su día Gómez Moreno, mucho menos, que no existieran restos homologable a éstos en Toledo ${ }^{71}$.

Al mismo tiempo, el hecho de que en ningún caso aparezcan paralelismos formales ni estructurales con los capiteles andalusíes ${ }^{72}$ y los datos documentales reseñados a propósito de la reconstrucción de iglesias por iniciativa de los monjes emigrados desde Córdoba (ver cuadro adjunto), nos obligan a pensar que el factor mozárabe — en sentido estricto- se concreta, precisamente, en el hecho de la reutilización, es decir, en ese pragmatismo constructivo que es rasgo cultural de Al-Andalus hasta la proclamación del califato.

71 Tal vez, se comprenda aquí la anterior alusión a un plateamiento «accidentalista» de la Historia. La «explicación» proporcionada por R. Corzo para «encajar» estos capiteles en la Alta Edad Media española, con ser «posible», es mucho más «improbable» que la manejada aquí y, en todo caso, resuelve peor los problemas de la cultura material de esos años. A no ser que estos capiteles hubieran sido realizados por un conjunto de personas que, en elkas mismas, materializaran los fenómenos culturales mencionados; en ese caso, sin embargo, tampoco sería «lógico» que la realización de las piezas hubiera tenido lugar en el siglo VII, cuando en todo el mundo mediterráneo ya se habían disuelto los conceptos ornamentales helenísticos en beneficio del «efectismo» bizantino, tal y como expuso en su día A. Riegel. En definitiva, aunque ante un debate en el que estamos discutiendo en una banda cronológica de cinco siglos, cincuenta años pudieran parecer «el chocolate del loro», lo cierto es que estos cincuenta años, que implican la recuperación de las hipótesis de Lampérez, implican también uno de los problemas culturales más importantes de todo el entramado cultural hispano: la noción misma de «cultura visigoda» y la «realidad cultural» de las zonas rurales del noroeste de la Península.

72 Los paralelismo formales citados por S. Noack, casi siempre sustanciados en motivos ornamentales elementales, a mi juicio, son poco relevantes y metodológicamente muy discutibles. Incluso en el supuesto de que, contra mi opinión, admitiéramos los talleres emirales del siglo IX, tal y como los definió Gómez Moreno, la correspondencia entre los capiteles emirales atribuidos a la época de Abd al-Rahman II y los leoneses podría explicarse a partir del origen común de unos y otros. 


\begin{tabular}{|c|c|c|c|c|}
\hline IGLLESIA & $\begin{array}{c}\text { REUTILIZACIONES } \\
\text { MANIFIESTAS }\end{array}$ & $\begin{array}{c}\text { REFERENCIAS } \\
\text { DOCUMENTALES } \\
\text { ANTERIORES } \\
\text { AL SIGLO X }\end{array}$ & CAPITELES & $\begin{array}{c}\text { CONSTRUCCIÓN } \\
\text { DE LA IGLESIA }\end{array}$ \\
\hline Bamba & Sí & Sí & $\begin{array}{l}\text { Bizantino, } \\
\text { s. V-VI }\end{array}$ & Testero, s. VII \\
\hline Mazote & Sí & No & $\begin{array}{l}\text { Entre los } \\
\text { s. IV? y VIII? } \\
\text { Lo más impor- } \\
\text { tante, del s. VI }\end{array}$ & Siglo $\mathrm{X}$ \\
\hline Escalada & Sí & Sí & $\begin{array}{l}2 \text { de s. IV-VI } \\
\text { Pórtico, s. VI } \\
\text { Resto, s. X }\end{array}$ & Siglo $\mathrm{X}$ \\
\hline Peñalba & No & Sí & Siglo VI & $\begin{array}{l}\text { Siglo VI (con } \\
\text { reparaciones } \\
\text { posteriores) }\end{array}$ \\
\hline Sahagún & Piezas sueltas & Sí & Siglo VI & \\
\hline $\begin{array}{l}\text { Hornija y } \\
\text { Toro }\end{array}$ & Piezas sueltas & Sí & $\begin{array}{l}\text { Entre los si- } \\
\text { glos IV y VII }\end{array}$ & \\
\hline Lebeña & No & No & $\begin{array}{l}\text { Finales del si- } \\
\text { glo VI }\end{array}$ & $\begin{array}{l}\text { Siglo VI (con } \\
\text { reparaciones } \\
\text { posteriores) }\end{array}$ \\
\hline
\end{tabular}

\section{B) CRONOLOGIA Y TALLERES}

Desde el punto de vista de su ubicación cronológica, la serie de capiteles de collarino «laureado» comprende un conjunto de variedades tipológicas y ornamentales que hace difícil creerlas producidas en un lapso cronológico de pocos años. Muy al contrario, incluso desde el punto de vista formal — de la evolución de las formas- da la sensación de que todos ellos reflejan un proceso de superposición cultural de cierta rapidez inicial pero que cumple por completo el periplo de este tipo de procesos: primeros contactos (superposición), asimilación y desarrollo autóctono e imbricación en la dinámica propia y disolución. De ahí que, resulte muy difícil atribuir todos los capiteles a un único taller activo durante un lapso cronológico corto, tal y como pretendía Gómez Moreno. A los primeros momentos de la segunda fase pertenecerían las series «más bizantinas» de Mazote seguidas de los de Sahagún, Peñalba, Escalada y algunos más de Mazote, con unos capiteles absolutamente integrados entre los productos materiales relacionados con la expansión de Bizancio, pero dotados de «personalidad propia». A la última fase, tal 
vez, prolongada hasta el siglo VII, corresponderían los de Lebeña, algunos de Hornija, las series más evolucionadas de Mazote y algunas piezas sueltas más, que señalan cómo, poco a poco, aquella corriente cultural inicial fue disolviéndose entre unos componentes rurales distintos de los que cimentaron el sustrato inicial.

En síntesis, se pueden acotar cuatro núcleos productivos coetáneos, dotados de otros tantos prototipos estructurales y ornamentales, una fase evolucionada, otra de desarrollo tardío y otra más de lo que podríamos llamar los primeros contactos, según el cuadro de la página siguiente.

En suma, los capiteles de collarino «laureado» informan de dos fenómenos culturales perfectamente individualizados:

a) Un impulso constructivo de carácter rural, muy posiblemente concretado hacia el siglo VI, al que pertenecieron dichos capiteles y, desde luego, Santiago de Peñalba y Santa María de Lebeña ${ }^{73}$.

b) Un fenómeno arquitectónico de evidente sentido mozárabe —en el más estricto sentido del término- regido por la síntesis de los dos fenómenos culturales que impone el hecho de la emigración.

Y si de la primera fase poco o muy poco es lo que podemos decir con cierta seguridad, habida cuenta la precariedad documental al respecto, no sucede lo mismo con la segunda. Puesto que el análisis de estos capiteles otorga una nueva y, a mi juicio, más ajustada interpretación del fenómeno mozárabe, en relación a las circunstancias históricas ambientales. Porque ahora podemos formular con absoluta seguridad que el fenómeno mozárabe es «lo que tenía que ser», es decir, una síntesis cultural entre los elementos del sistema cultural propios del componente «superestructural», aportados por los monjes andaluces, y los que dependen de la «infraestructura» del lugar de asentamiento, determinados por la estructura social de la zona astur-leonesa. Así, pues, el componente cultural hispanoislámico estaría, más que en el uso de soluciones formales andalusíes, en la concepción global arquitectónica ${ }^{74} \mathrm{y}$, desde luego, en ese pragmatismo que caracterizó a la arquitectura cordobesa anterior a la proclamación del califa-

${ }^{73}$ Un fenómeno de expansión arquitectónica que, a falta de otros datos y de acuerdo con los que conocemos, he propuesto relacionar con la única iniciativa documentada que, situada en pleno siglo VI, concuerda con lo que informan los capiteles: la promoción monacal personalizada en Martín de Braga, un personaje que, como planteara hace tiempo, concreta en su propia persona los mismos rasgos culturales que reflejan estos capiteles. No obstante, deseo dejar muy claro que ésta es una «adjudicación forzada», que en su sentido personalizador, tiene muy poco que ver con mi metodología y casi resulta anecdótico. Desde mi punto de vista, lo importante es la adscripción cultural de estos restos y en ese sentido, debo reconocer la escasa relevancia de la aportación de este análisis, puesto que todo ello ya lo había formulado G6mez Moreno, aunque sus conclusiones finales fueran muy distintas de las mías. En todo caso, debo insistir en que la solución definitiva del problema institucional que pueda promover esta «reclasificación» es algo que trasciende por completo mis posibilidades y los objetivos que me tracé cuando afronté el análisis de los capiteles hispanos altomedievales. Por mi parte, dentro de la más estricta militancia «chikliana», me he limitado a destacar «lo que dicen» los restos de cultura material en cuestión, que es cosa muy distinta de lo que se ha venido interpretando.

${ }^{74}$ Esta concepción global arquitectónica estaría impuesta, cuando ello fuera posible, es decir, cuando hubiera que construir la iglesia por completo, por los rituales mozárabes y, por lo tanto, por los prototipos religiosos de las comunidades asentadas en zona islamizada, de los que por desgracia, nada conocemos. 
FASE CULTURAL Y CRONOLOGÍA

PIEZAS

Capitel de Bamba

APARICIÓN DEL INFLUJO BIZANTINO.

HACIA EL 500
RASGOS MATERIALES MÁS SOBRESALIENTES

Pieza homologable con los modelos bizantinos.
Mazote, al menos, las series SCM1, SCM2, SCM4

Capiteles de fuerte bizantinismo con rasgos de originalidad creativa (conjugación de formas, ábacos y cimacios).

Edificaciones con columnas exentas.

\section{DESARROLLO \\ AUTÓCTONO DEL FOCO BIZANTINO.}

S. VI
Capiteles «bizantinizantes» con remanentes helenistas.

Pórtico de Escalada

Santiago de Peñalba

Piezas sueltas similares

Iglesias tipo Peñalba o Lebeña, con pocas columnas exentas.

Series de Hornija y Toro

Prototipos ornamentales de fuerte personalidad.

Dispersión tipológica y modular.

Posibles iglesias de cierta entidad.

\section{Sahagún}

Capiteles «bizantinizantes» con remanentes helenistas.

Posible edificación de entidad.

\begin{tabular}{l}
\hline NÚCLEO Lebeña \\
EVOLUCIONADO \\
HACIA EL 600
\end{tabular}

\section{FASE DE DISOLUCIÓN} SIGLO VII
Series «degeneradas» de Mazote, Oviedo (catedral, Museo y Lena), capitel suelto de Escalada, imposta de Bamba, Cellórigo, etc.
Pérdida del virtuosismo de la fase anterior (soluciones «efectistas» de menor complejidad técnica).

Degeneración de los rasgos bizantinizantes y de tradición helenística (pérdida de la estructura orgánica del orden). 
to, que se manifiesta de modo irregular pero, sobre todo, acudiendo al uso de restos de acarreo $^{75} \mathrm{o}$, incluso, en la rehabilitación de edificios que habían llegado a los siglos IX y X en estados de conservación muy diversos. Así, pues, Peñalba y Lebeña se encontrarían prácticamente intactas (al menos, hasta la altura de los capiteles) ${ }^{76}$; San Miguel de Escalada ${ }^{77}$ y San Cebrián de Mazote serían reconstruidas prácticamente por completo, lo que explicaría su relativa similitud espacial y estructural (el mayor orientalismo de ambas), fuertemente caracterizadas frente a las otras dos iglesias.

El componente cultural astur-leonés se manifestaría en el resto de los rasgos materiales, es decir, en todos aquellos supeditados a la mano de obra autóctona, a los medios tecnológicos y materiales disponibles, $\mathrm{y}$ en especial, en los elementos ornamentales realizados al efecto, como los capiteles de Escalada que sí fueron realizados en el siglo $\mathrm{X}$.

\section{BIBLIOGRAFÍA}

Agnello, G.: «I capitelli Bizantini del Museo di Messina», Rivista dei Archeologia Cristiana, XLII, I-4, 1966, pp. 9-29.

ANGElis D'OSSAT, G. DE y FARIOLI, R.: «Il Complesso paleocristiano di Braviglieri (El Khadra)», Quaderni di Archeologia della Libia, 7, 1975, pp. 27-156.

BANGO TORVISO, I.: «Arquitectura de la décima centuria» ¿Repoblación o mozárabe?, Goya, 122, 1974. pp. 68-75.

BANGO TORVISO, I.: «El neovisigotismo artístico del siglo x: la restauración de ciudades y templos», Ideas estéticas, 1979, pp. 319-338.

BANGO TORVISO, I.: "Historia del arte cristiano en España (siglos VIII al XII)», en Historia de la Iglesia en España dir. por García Villoslada, Madrid, 1982, t. II, $1^{a}$, pp. 497-572.

BECKWITH, J.: Coptic Sculpture, London, 1963.

BUCHWALD, H.: «Eleventh Century corinthian-palmette capitals in the region of Aquileia», The Art BuIletin, XLVIII, 1966, pp. 147-159.

CABALlero Zoreda, L.: La iglesia y monasterio visigodos de Santa María de Melque, Madrid, 1980.

CABAllero Zoreda, L.: «Una conjetura sobre la iglesia de San Pedro de la Nave», I Congreso de Historia de Zamora, Zamora, (1988), 1990, II, pp. 317-355.

CABALLERO ZOREDA, L.: «Pervivencia de elementos visigodos en la transición al mundo medieval. Planteamiento del tema", III Congreso de Arqueología Medieval Española, Oviedo, 1989, pp. 113-134.

CAMÓN AZNAR, J.: «Arquitectura española del siglo X. Mozárabe y de repoblación», Goya, 52, 1963, pp. 206-219.

COLASANTI, A.: L'Arte bizantina in Italia, Milán, 1923.

Coloquio Internacional de Capiteles, Madrid, 1991,

Corzo, R.: San Pedro de la Nave. Estudio histórico y arqueológico de la iglesia visigoda, Zamora, 1986.

CORzo, R.: Visigótico y Mozárabe, vol XVI de Historia del Arte, Madrid, Historia 16, 1989.

CRESSIER, P.: «Les chapiteaux de la Grande Mosqueé de Cordoue», Bulletin d'Archéologie Marocaine, XIII, 1984, pp. 253-301.

75 Cualidad que, desde luego, no es privativa de la cultura andalusí, porque el uso de material de acarreo también se advierte en la arquitectura asturiana.

${ }^{76}$ En este sentido deseo manifestar, de modo explícito, mi voluntad de no pronunciarme, por el momento, a propósito de las cubiertas de estas dos iglesias; no obstante, es de suponer que esas zonas serían las más proclives a sufrir los rigores del abandono.

77 Es muy probable que el resto de los relieves de Escalada sean también del siglo $\mathrm{x}$. 
CRESSIER, P.: "Les chapiteaux de la Grande Mosqueé de Cordoue et la sculpture de chapiteaux al'époque émiral», Madrider Mitteilungen, 25, 1984, pp. 216-281.

CRESSII:R, P.: «Les chapiteaux de la Grande Mosqueé de Cordoue et la sculpture de chapiteaux al'époque émiral», Madrider Mitteilungen, 25, 1984, pp. 257-313.

CRESSIER, P. «Le chapiteau emiral: les problemes de son etude», Coloquio Internacional de Capiteles, Madrid, 1991, pp. 87-102.

Deichmann, F. W.: "Il capitello paleocristiano», Corsi di Cultura sull'Arte Ravennate e Bizantina, 2. 1956. pp. 41-59.

Dominguez Perela, E.: «Los capiteles hispanomusulmanes altomedievales (hasta el año 1000). Sistemas de proporciones y metrología. Primeros resultados», Boletín de la Asociación Española de Orientalistas, XIX, 1983, t. I, pp. 123-161.

DOMinguez PERElA, E.: «Los capiteles del pórtico de Escalada entre la tradición clásica y bizantina, lo islámico y la creación local», V Congreso Español de Historia del Arte, Barcelona, 1984.

Dominguez PeRela, E.: Capiteles Hispánicos Altomedievales, Madrid, Universidad Complutense, 1987.

Dominguez PerelA, E.: «Los capiteles de Al-Andalus durante los siglos VIII-IX» Coloquio Internacional de Capiteles, Madrid, 1991, pp. 103-118.

Domínguez PerelA, E.: «Problemas de capiteles. A proposito del libro de Ramon Corzo, sobre "visigótico y prerrománico" y del artículo de Carlos Márquez sobre capiteles romanos», Archivo Español de Arqueología, 1991, p. 335-350.

DuChESNE, L.: L'Eglise au Vlème siècle, Paris, E. de Boccard, 1925.

Duval, N. y Lézine, A.: «Necropole chrétienne et Baptistère souterrain à Carthage», Cahiers Archéologiques. Fin de l'Antiquité et Moyen Age, X, 1959, pp. 71-156.

DUVAL, N.: Les églises à deux absides, Paris, 1971.

FARIOLI, R.: Corpus della scultura paleocristiana bizantina ed altomedievale di Ravenna, III. La scultura architettonica, Roma, 1969.

FILARSKA, B.: «Nouveaux fragments de chapiteaux hétérodoxes à Palmyre», Travaux du Centre d'Archeologie Méditerranée de l'Academie Polonaise des Sciences, 1966, pp. 123-128.

FIRETLI, N.: «Encore une façade de faux sargophages», Cahiers Archeologiques, Fin de l'Antiquité et Moyen Age, XXIII, 1974, pp. 33-44.

FIRETLI, N.: «Deux chapiteaux rares à décoration animale trouvés à Istambul», Cahiers Archeologiques, Fin de l'Antiquité et Moyen Age, XXIII, 1974, pp. 33-44.

FONTAINE, J.: L'art prérroman hispanique, Paris, 1973 (ed. cast., Madrid, 1978)

GANDOLFO, F.: «I capitelli della cripta abbaziale di Novantola», Annuario del Instituto di Storia dell'Arte, 1974-75, 75-76, pp. 5-39.

GARCIA ROMO, F.: La escultura del siglo XI y sus precedentes hispánicos, Barcelona, 1973.

García Villoslada, R. (ed.): Historia de la Iglesia en España, I, Madrid, 1979.

Gómez MOREnO, M.: Iglesias mozárabes, Madrid, 1919.

Gómez Moreno, M.: Catálogo monumental de la provincia de León, Madrid, 1926.

GÓMEZ MORENO, M.: Catálogo monumental de la provincia de Zamora, Madrid, 1927.

Gómez Moreno, M.: Arte árabe español hasta los almohades, Ars Hispaniae, III, Madrid, 1951.

GRABAR, A.: Le premier art chrétien (200-395), Paris, 1966.

GRAVIERS, J. des: «Inventaire des objets copts de la salle de Baunil au Louvre», Rivista di Archeologia Cristiana, IX, 1932, pp. 51-103.

GutíERREZ BEHEMERID, M. A.: «El capitel corintizante. Su difusión en la península Ibérica», Boletín del Seminario de Arte y Arqueología, XLIX, 1983, pp. 73-93. (Ver también el resto de sus artículos en esa misma revista).

HARRAZI, N.: Chapiteaux de la grande Mosquée de Kairouan, Tunis, 1982.

Hammann, S.: Vorgeschichte und Geschichte der sueben in Spanien, Munich, 1971.

Hammond, P. C.: «The capitals from the temple of the Winged Lions, Petra», Bulletin of the American 
Schools of Oriental Research. 226. 1977. pp. 47-51. (ver, también del mismo autor, sus memorias de excavación en Petra en el Annual of the Department of Antiquities, en especial, a partir de 1975).

HERNÁNDEZ JIMÉNEZ, F.: «Un aspecto de la influencia del arte califal en Cataluña (basas y capiteles del siglo XI)", Archivo Español de Arte y Arqueología. VI, 1930, pp. 21-49.

KaUTZSCH, R.: Kapitellestudien Baiträge zu einer Geschichte des spätantiken Kapitells im Osten von 4 bis ins. 7. Jahrhudert, Berlín, Leipzig, 1936.

LAMPÉrez y RomeA, V.: «La iglesia de San Cebrián de Mazote», Boletín de la Sociedad Española de Excursionistas, X. 1902, pp. 185-193.

LAMPÉREZ y ROMEA, V.: La iglesia de San Cebrián de Mazote, notas sobre algunos monumentos de la arquitectura cristiana española, segunda serie, 1904.

Lampérez y Romea, V.: «La iglesia de San Cebrián de Mazote», Boletin de la Real Academia de la Historia, LXIX, 19/6, pp. 231-235.

LAMPÉREZ y ROMEA, V.: Historia de la arquitectura cristiana española en la Edad Media, t. 1, 2" ed., Madrid, Barcelona, 1930.

Luengo y Martínez, J. M.: «De la Tebaida leonesa. Montes y Peñalba», Tierras de León, II, 1962. pp. $25-42$.

Martínez Diez, G.: «La colección canónica de la Iglesia Sueva», Bracara Augustea, 21, 1967. pp. 224-243.

MARTínez Díez, G.: «Los concilios suevos de Braga en las colecciones canónicas de los siglos VI-XII», en El Concilio de Braga y la función de la legislación particular en la Iglesia, Salamanca, 1975. pp. 93-105.

NOACK-HALEY, S.: «Typologische Untersuchungen zu den mozarabischen Kapitellen von San Cebrián de Mazote», Madrider Mitteilungen, XXVI, 1985, pp. 314-345.

NOACK-HALEY, S.: «En torno al "arte mozárabe”», II, Congreso de Arqueología Medieval Española, Madrid, 1987.

NOACK-Haley, S.: «Capiteles mozárabes», Coloquio Internacional de Capiteles, Madrid, 1991. pp. 37-52.

NOACK-Haley, S.: Mozarabischr Baudekor I: Die Kapitelle, Madrider Beiträge, 19, 1991.

Panazza G. y TAgliaferri, A.: Corpus della Scultura Altomedievale, III. La Diocesi di Brescia, Spoleto, 1966 .

PANI ERmini, L.: Corpus della Scultura Altomedievale, VII. La Dicesi di Roma, t. I, la IV Regione Ecclesiastica, Spoleto, 1974.

PANI ERminI, L.: Corpus della Scultura Altomedievale, VII. La Dicesi di Roma, t. II, La racolta dei fori imperiali, Spoleto, 1974.

PENSABENE, P.: «Un'officina greca per gli elementi decorativi architettonici dell'anfiteatro di Laccem», Ricerche e Studi, Quaderni del Museo Provinciale Francesco Ribezzo di Brindisi, 6, 1972, pp. 9-39.

Pensabene, P.: Scavi di Ostia, $t$. VII, I Capitelli, Roma, 1973.

PENSABENE, P.: "La decorazione architettonica di Cherecel: cornici, architravi, sofitti, bai e pilastri», 150Jahr-Feier, Deutsches Archäologisches Institut at Roma, 1979, pp. 116-169.

Pensabene, P. y Degrissi, A.: «Frammenti antiche del convento di San Alesio», Quaderni di Storia dell'arte, 20, 1982.

Pita AndRade, J. M.: Tierras de España, Castilla y León, Madrid, 1975.

PUIG I CADAFALCH, J.: L'art wisighotique et ses survivances, Paris, 1961.

RASPI SERRA, J.: «Sculture tardoantiche, paleocristiane ed altomedioevali do Otranto», Bollettino d'arte, 1972 , pp. 138-143.

RodrfGuez Alonso, C.: Las historias de los godos, vándalos y suevos de San Isidoro de Sevilla, León, 1975.

ROLLÁN ORTIZ, J. F.: Iglesias mozárabes leonesas, Madrid, Everest, 1976.

RONCZEWSKY, C.: «Variantes des chapiteaux romains», Acta Universitatis Latviensis, VIII, 1923, pp. 115-171. 
SAyAS, J. J. y Garcia MOREno, L. A.: Romanismo y germanismo. El despertar de los pueblos hispánicos. Barcelona, 1982.

SCHL.UNK, H.: Arte visigodo, arte asturiano, en Ars Hispaniae. t. II, Madrid, 1947.

ScHL.uNk. H.: «Relaciones entre la península lbérica y Bizancio durante la época visigoda», Archivo Español de Arqueología, 60, 1945.

Scillunk. H.: "Los monumentos paleocristianos de Gallaecia, especialmente los de la provincia de Lugon, Actas del Coloquio Internacional sobre el Bimilenario de Lugo, Lugo, 1977. pp. 193-236.

SEVERIN, H. G.: «Problemi di scultura tardoantica in Egitto", 28 Corso di Cultura sull'Arte Ravennate e Bizantino, Ravenna. 1981.pp. 315-336.

SHEPPARD, CARL D.: «Pre-Romanesque Sculture: Evidence for the Cultural Evolution of the People of the Dalmatina Coast", Gesta, XXIII, I, 1984, pp. 7-16

SIMONET, Fr. J.: Historia de los mozárabes de España, Madrid, 1897-1903 (reedición, 1983).

SPELTZ, A.: The Styles of Ornament. New York, 1959.

STRONG, D.E.: $y$ Ward Perkins, J.B.: «The temple of Castor in the Forum Romanun», Papers of the Brituish School at Rome, XXX, 1962, pp. 1-30.

STRUBE, Ch.: «Die Formgebung der Apsisdekoration in Qalbloze und Qalat Siman», Jahrhuch für Antike und Christentun, 20, 1977, pp. 181-191.

TAVANO, S.: «Constantinopoli, Ravenna e l'Alto Adriatico: La scultura architettonica dell'Antichità al Medio Evo", Antichità Altoadriatiche, XIII, 1978, pp. 505-536.

TORP, H.: «The carved decorations of the North and South Churches of Bawit», Kolloquium über Spätantike und Frühmittelalterliche Skulptur. Mainz am Rheim. 1970, t. II. pp. 35-41.

THOUVENOT, R.: «Sur quelques chapiteaux singuliers de Banasa», Bulletin archéologique du Comité des travaux historiques et scientifiques, 6, 1970, pp. 245-254.

VERGARA, P. C.: «Elementi architettonici tardoantichi e medioevali nella cripta della cattedrale di Otranton, Rivista dell'Instituto Nazionale d'Archeologia e Storia dell'Arte, IV. 1981, pp. 71-103.

VERZONE, P.: «I capitelli del tipo corinzio dal IV all'VIII secolo», Forschungen zur Kunstgeschichte und Christlichen Archäologie, 2, 1953, pp. 87-97.

WALTERS, C. C.: Monastic Archaology in Aegypt, Warminster, 1974.

WARD PERKINS, J. B.: «Tripolitania and the marbre trade», The Journal of Roman Studies, XLI, 195I. pp. 105-111.

Ward Perkins, J. B.: «Nicomedia and the marble trade», Papers of the British School at Rome, XLVIII. 1980, pp. 23-69.

WeCkernagel., M.: Die Plastik des II und I2 Jahrhunderts in Apulien, Leipzig, 1911. 